\title{
Origin of step-like and lobate seafloor features along the continental shelf off Rio de Janeiro State, Santos basin-Brazil
}

\author{
A.T. Reis ${ }^{a, *}$, R.M.C. Maia ${ }^{b}$, C.G. Silva ${ }^{b}$, M. Rabineau ${ }^{c}$, J.V. Guerra $^{a}$, C. Gorini ${ }^{d}$, A. Ayres ${ }^{b}$, \\ R. Arantes-Oliveira ${ }^{a}, M$. Benabdellouahed ${ }^{\mathrm{e}}$, I. Simões ${ }^{f}$, R. Tardin ${ }^{\mathrm{a}}$
}

\begin{abstract}
a Departamento de Oceanografia Geológica, Faculdade de Oceanografia, Universidade do Estado do Rio de Janeiro (UERJ), Rua São Francisco Xavier, 524, Maracanã, CEP 20.550-900 Rio de Janeiro/RJ, Brazil

${ }^{b}$ Departamento de Geologia/LAGEMAR, Instituto de Geociências, Universidade Federal Fluminense (UFF), Av. Gen. Milton Tavares de Souza, s/no. 4 andar, Campus da Praia Vermelha, Gragoatá, CEP 24210-346 Niterói/RJ, Brazil

${ }^{c}$ CNRS, Domaines Océaniques (UMR6538), Equipe Transferts Terre-Mer, Institut Universitaire des Sciences de la Mer (IUEM), Université de Bretagne Occidentale (UBO). 1, Place N. Copernic, Plouzané 29280, France

${ }^{d}$ Laboratoire Evolution et Modélisation des Bassins Sédimentaires, Institut de Science de la Terre-ISTEP (UMR CNRS 7193), Université Pierre et Marie Curie-Paris 6, 4 Place Jussieu, 75005 Paris, France

e Ifremer Centre de Brest, DRO/Géosciences Marines, B.P. 70, 29280 Plouzané Cedex, France

${ }^{f}$ Instituto de Estudos do Mar Almirante Paulo Moreira (IEAPM), Praça Daniel Barreto s/no., Praia dos Anjos, CEP 28.930-000 Arraial do Cabo/RJ, Brazil
\end{abstract}

*: Corresponding author : A. T. Reis, email address : antonio.tadeu@pq.cnpq.br

\begin{abstract}
:
A combined analysis of seismic and morphological features identified in a set of high-resolution seismic reflection and bathymetric data, shows a systematic relationship between major modern seafloor morphological traces and the basinward migration of Late Pleistocene coastlines along the continental shelf of the Santos basin (Rio de Janeiro State, SE Brazil). Observed fairly continuous and sinuous mid-outer shelf escarpments are related to the sea-level variations and shelf exposure during the Last Glacial cycle. A bathymetric step at $-110 \mathrm{~m}$ is an erosional remnant of offlapping detached forced-regressive wedges that spread over $50 \mathrm{~km}$ in the shelf-dip direction, probably developed during periods of falling sea level between MIS 3 and 2. A second major escarpment at $-130 \mathrm{~m}$ was interpreted as the shoreline during the LGM, at the time of most extensive subaerial exposure of the continental shelf. However, a distal escarpment at $-150 \mathrm{~m}$ is expressed as a straight contour feature along the two main shelf-edge embayments that characterize the shelf break. This escarpment is coupled with a basal seaward-inclined and highly eroded ramp, and was interpreted as the erosional action of bottom currents during the last transgression due to the displacement of the southward flowing Brazil Current towards the present-day outer shelf. Previously published articles have regarded the morphological features observed on the modern shelf as indicators of stillstands during the postLGM transgression. We conclude that, on the contrary, most of these features are actually from earlier parts of the Late Pleistocene and were formed in a regressive scenario under oscillating and relative slow sea-level fall.
\end{abstract}




\section{Highlights}

Geomorphologic indicators of Latest Quaternary sea-level oscillations Drowned outer shelf deposits related to stepped forced-regressive wedges - Linear bathymetric steps formed during the Late Pleistocene sea level regression - Last Glacial Maximum shoreline preserved at $130 \mathrm{~m}$ below modern sea level $\$ Escarpment at $-150 \mathrm{~m}$ sculpted by the southward flowing Brazil Current

Keywords: Continental shelf geomorphology ; Forced regression ; LGM shoreline ; Late Pleistocene ; Post-LGM transgression ; Brazil Current

\section{Introduction}

Drowned Late Pleistocene-Early Holocene features remain poorly documented on the continental shelf off southern Rio de Janeiro State (referred to hereafter as RJ; Fig. 1), in the northern Santos basin, as well as on the entire Brazilian continental margin as a whole. In this context, high resolution seismic stratigraphic studies may provide valuable information for the understanding of the glacioeustatic meaning of subsurface shelf architecture and surface shelf morphology. However, until recently, the geomorphological evolution of drowned seabed features observed on the southern RJ shelf had been investigated only through the examination of conventional bathymetric survey data. A few pioneer studies carried out in the 1970s and 1980s (Zembruscki, 1979, Corrêa et al., 1980 and Costa et al., 1988) interpreted the origin of a series of continuous linear step-like 
seabed features as the geomorphic indicators of palaeoshorelines (beach sand ridges) developed during successive stages of sea-level stillstand around the present-day $25,32,50,60,90$ and $110-\mathrm{m}$ isobaths, in the course of the latest Pleistocene-Holocene transgression, while a continuous escarpment located at -130 m was correlated to shoreface features related to the Last Glacial Maximum (LGM) (Costa et al., 1988).

Due to the scarcity of seismic surveys and sediment coring, the Upper Pleistocene-Holocene stratigraphy of the continental shelf off the southern RJ margin remained poorly explored until Maia et al. (2010) recently addressed the stratigraphic framework of the shallow sedimentary record ( $2300 \mathrm{~ms})$ of this area. The combined analysis of a recovered set of vintage sparker paper seismic records (500-1000 J) acquired in the early 80's, chronostratigraphic data from the oil industry's exploratory wells (Fig. 1) and $\delta^{18} \mathrm{O}$-derived information on glaciation-related global sea-level variations (Marine Isotope Stages, MIS), led to the identification of 5 major seismic sequences (Sq1-Sq5) interpreted as a succession of depositional sequences induced by repeated glacioeustatic cycles of alternating fall and rise, spanning the last $\sim 500 \mathrm{kyr}$ of the Quaternary. On the interpreted sparker seismic lines, sequences Sq1-Sq4 enclose mainly outer shelf progradational components (shelf wedge prisms) interpreted as relatively poorlypreserved forced-regressive depositional sequences that each record a $\sim 100-\mathrm{kyr}$ long glacioeustatic cycle, whereas the sedimentary unit labelled Sq5 was interpreted to represent the transgressive and highstand deposition of the current half-cycle (post-LGM, Holocene).

Thanks to the recent acquisition of a dataset of sub-bottom chirp profiles $(\sim 500-5,500 \mathrm{~Hz})$, that has been combined with existing bathymetric data, we could for the first time look into the stratigraphic organization of shelf sedimentary systems at a higher resolution, down to about $100 \mathrm{~ms}$ below the 
seafloor. It was thus possible to explore the Upper Pleistocene-Holocene (last 120 kyr) shelf sedimentary architecture and recognize the aggradational and highstand architectural elements contained within the uppermost seismic sequences Sq4 and Sq5 identified by Maia et al. (2010). The datasets analyzed allowed the reinterpretation of the stratigraphic meaning of the continuous seabed features recognized across the continental shelf off southern RJ. In the light of the present-day understanding of the high resolution seismic sequence and Late Pleistocene to Holocene sea-level curves proposed worldwide, the origin of the linear seafloor features are ascribed to distinct glacio-eustatic stages.

This research provides a case study of a relatively starved shelf from the rather unexplored quaternary Brazilian continental margin, making unpublished information available to a worldwide audience.

\section{BACKGROUND}

Landward of the Santos basin's northern sector lies the Serra do Mar, a long coastal mountain range very close to the present day coastline. Tertiary (Early Oligocene) tectonic reactivation events of this coastal mountain range led to the reorganisation of drainage systems that delivered sediments directly into Santos basin. Drainage systems were captured and diverted to the neighbouring Campos basin and reorganised as the coast-parallel Paraíba do Sul river system (Fig. 1) (Modica and Brush, 2004). As a consequence, the shelf environment became relatively starved of clastic input. The shelf edge stepped back more than $50 \mathrm{~km}$ landward of the Late Eocene position, to a position close to that maintained at present. This configuration (Fig. 1) evolved into today's landscape of narrow coastal plains and small rivers, draining mainly Precambrian crystalline rocks, that terminate either directly into open sea or into the partially-enclosed coastal environments such as Ilha Grande, Sepetiba and Guanabara bays 
117 (Milliman, 1978; Zalán and Oliveira, 2005). The continental shelf off southern RJ

118 has thus been classically regarded as a sediment-starved shelf (e.g. Milliman,

119 1978; Kowsmann et al., 1977; Kowsmann et al., 1979; Kowsmann and Costa,

120 1979; Zembruscki, 1979) developed in the context of a thermally-old and

121 tectonic stable margin (Chang et al., 1992; Cainnelli and Mohriak, 1999).

\subsection{Shelf morphology, oceanography and surface sediment distribution}

The study area is a low-gradient moderate- to high-energy continental shelf, affected by the passage of winter frontal systems. It is a microtidal shelf where tidal currents seem to be more important in the across-shelf direction (Alves, 1992). The shelf break is irregular displaying large re-entrants and upper slope morphological plateaus between Cabo Frio and São Sebastião island (Fig. 1), possibly related to the action of contour currents (Duarte and Viana, 2007). Cape arguably is the most conspicuous geomorphic feature of the study area, accompanied by important changes in shelf width and gradient. Off Cabo Frio cape the $100-\mathrm{m}$ isobath lies less than $10 \mathrm{~km}$ from the coastline, while farther south it is located $\sim 80 \mathrm{~km}$ away from Ilha Grande island (Fig. 1). The feature has important implications for the shelf hydraulic regime and is associated with changes in the Brazil Current (BC) trajectory (Signorini 1978; Campos et al., 2000; Silveira et al., 2000; Rodrigues and Lorenzzetti, 2001). The BC is a western boundary contour current associated with the South Atlantic subtropical gyre. It arises as a shallow and weak current at approximately $14.5-15.0^{\circ} \mathrm{S}$ 140 (Stramma and England 1999; Soutelino, 2008) becoming gradually deeper 141 (thicker) and stronger as it moves to the SW, roughly following the orientation of the shelf break / upper slope. Between 22 and $23^{\circ} \mathrm{S}$, the BC transports Tropical 
by the water surface and the bottom of the picnocline (Silveira et al., 2000).

Coastline configuration, continental margin bathymetry and the $\mathrm{BC}$ together affect sedimentation patterns (Fig. 2) and geochemical characteristics of the continental shelf and upper continental slope (Mahiques et al., 2004). Despite the frequent occurrence of BC eddies around the Cabo Frio cape area (Silveira et al., 2000; Mahiques et al., 2005; Calado et al., 2010), their influence on the shelf and upper slope sediment dynamics remains largely unknown. Duarte and Viana (2007) have discussed the role of BC eddies in reworking bottom sediment and as an important erosive agent in the sculpturing of shelf-edge embayments between Cabo Frio and São Sebastião island (Fig. 1). Recent studies by Nagai et al. (2010), based on multiproxy analyses (sedimentology, geochemistry and biostratigraphy), have highlighted changes in oceanic productivity and circulation on the Brazilian southeastern upper continental margin for the last $27 \mathrm{kyr}$. During the LGM, the fallen sea level, increased productivity and lowered seasurface temperatures may be considered the result of offshore displacement of the main flow of the BC. During the post-LGM transgression, the increase in water column temperature and more intense geomorphological work by the BC suggest a displacement of its warm waters towards the coast.

\subsection{Quaternary stratigraphy}

Maia et al. (2010) first proposed a Pliocene-Quaternary stratigraphic framework for the continental shelf off southern RJ, based on a combined analysis of sparker seismic records (500-1000 J) acquired in the early 80's (Geomar cruises; Fig. 3). The framework is composed mostly of stacked clinoformal seismic units representing up to eight major seismic sequences bounded by angular unconformities. According to their internal architecture and 
the geometry of the recognized clinoforms, the seismic sequences were grouped into two distinct stratigraphic sets identified as Set I (SqA-SqC) and Set II (Sq1172 Sq5). Reflectors S1 to S5 are erosive and frequently show stepped surfaces. 173 They truncate the underlying seismic sequences Sq1 to Sq4, as shown by many 174 toplap terminations. Surfaces S2, S3 and S4 bound sequences of limited updip extent. The three surfaces merge landward with surface S1 to become shelf-wide erosive surfaces. Each of these seismic horizons is interpreted as a master sequence boundary, representing a diachronous period of erosion from during times of deepest sea-level falls and lowstands, i.e. when subaerial exposure of the shelf was most extensive. These surfaces (Fig. 3) were reworked during subsequent times of sea-level rise.

Chronostratigraphic data (Nannofossil zonation) from oil-industry exploratory wells enabled us to attribute an age younger than about 440-500 kyr to the five seismic sequences of Set II (Maia et al. 2010; Fig. 3). Considering that in their internal geometry and style of bounding surfaces, the sequences Sq1-Sq4 mimic each other, it was proposed that they record fourth-order depositional cycles of $\sim 100-\mathrm{kyr}$ periodicity, matching $\delta^{18} \mathrm{O}$-derived global sealevel data (Fig. 3c). Sequence Sq5 does not reflect a depositional sequence in the either to be an inner shelf highstand sedimentary prism, or to be patchy outersame sense as sequences Sq1-Sq4. Sq5 (of limited extent and thickness) would represent transgressive and highstand deposition during the Holocene and be part of a youngest sequence, just beginning its development (Fig. 3).

Due to the limited resolution of the sparker seismic reflection data, depositional sequence Sq4 was poorly imaged in the mid-shelf while in the outer shelf area only its progradational forced-regression components were clearly identified. Sq5 was considered a rather unevenly distributed layer, interpreted shelf transgressive sedimentary cover of local preservation favoured by erosive 
depressions that would have pre-existed imprinted on surface S5. Surface S5 was thus mapped as representing the present-day seafloor across great parts of the shelf (Fig. 3).

\section{MATERIAL AND METHODS}

The seismic stratigraphic and geomorphological analysis in this study integrates 2D high-resolution seismic line data interpretations, newly acquired high-resolution chirp seismic profiling and newly compiled bathymetric data (Fig. 1). The seismic dataset encompasses: (1) $\sim 1,500 \mathrm{~km}$ of sub-bottom profiling acquired in August 2010 during leg 2 of the oceanographic cruise RIO COSTA 1, aboard the Brazilian $R / V$ Cruzeiro do Sul. Acquisition was performed with a surface tow Edgetech SB-501i sub-bottom profiler using full spectrum chirp technology (signal frequency between $\sim 500-5,500 \mathrm{~Hz}$ ) that provides highresolution sub-bottom imagery of up to circa $100 \mathrm{~ms}$ penetration into the subfloor, with a vertical resolution of $\sim 2-5 \mathrm{~m}$; and (2) $\sim 5,000 \mathrm{~km}$ of single-channel vintage paper sparker seismic lines (500-1000 J oules, 100 to $1400 \mathrm{~Hz}$ ), acquired in the early 1980ies, during GEOMAR Oceanographic Cruises $^{1}$ (Fig. 1). Maximum signal penetration ranged from 300 to $350 \mathrm{~ms}$, while the vertical resolution oscillated between 7 and $12 \mathrm{~m}$, depending on the seismic line considered. To calculate the thickness of each seismic sequence, an estimated layer velocity of $1600 \mathrm{~m} / \mathrm{s}$ was considered. Analysis of seismic data followed established highresolution seismic and sequence stratigraphic methods (in terms of reflector truncation and configuration), and allowed for identification of depositional

\footnotetext{
${ }^{1}$ A total of 24 legs of GEOMAR oceanographic cruises were carried out between 1972 and 1986 in a joint scientific programme between the Woods Hole Oceanographic Institute, Brazilian universities, governmental agencies and companies, aiming at the acquisition of seismic data, sub-bottom profiling and surficial-sediment sampling throughout the Brazilian continental shelf and slope.
} 
sequences and their boundaries (Mitchum et al., 1977a; Mitchum et al., 1977b;

Catuneanu, 2006).

In the absence of swath bathymetric data, imagery of the sea-floor morphology was achieved through the compilation of tens of Brazilian Navy bathymetric sounding charts spanning over 50 years, made available by $\mathrm{CHM}$ Centro Hidrográfico da Marinha do Brasil (the hydrographic center of the Brazilian Navy). This compilation of bathymetric data offered a horizontal sampling of $\sim 400 \mathrm{~m}$ on the continental shelf (between water depths of $\sim 20 \mathrm{~m}$ and $\sim 200 \mathrm{~m}$ ) and $\sim 1 \mathrm{~km}$ on the upper slope. For the continental slope, ETOPO2 regional data (Smith and Sandwell, 1997) was included, making up for the relative low coverage of the navy's dataset.

As no deep cores are available on the shelf, we had no independent ages of palaeoshorelines nor of measured or estimated sea-level curves established in the area. In far-field tropical regions such as our study area, away from former ice masses and related zones of marked glacio-isostatic effects, we could use as a first approximation, a series of relatively precise global sea-level curves that have been established based on analyses of deep sea foraminifera $\delta^{18} \mathrm{O}$ isotope records, calibrated by direct measurements of sea-level position extracted from geological evidences (shoreline position) or using corals (e g. I mbrie et al., 1984; Chappel and Shackleton, 1986; Labeyrie et al., 1987; Fairbanks, 1989; Bard et al., 1990; Bassinot et al., 1994; Szabo et al., 1994; Lambeck, 1997; Rohling et al., 1998; Toscano and Lundberg, 1999; Shackleton, 2000; Lambeck and Chappell, 2001; Waelbroeck et al., 2002; Cutler et al., 2003; Rabineau et al., 2006); or still using stratigraphic models (e.g. Skene et al., 1998) and a hydraulic model of water exchange (Siddal et al., 2003), as synthesized in Rabineau et al. (2006). 


\subsection{Shelf seafloor morphology}

The E-W-oriented continental shelf of the study area extends for about 400 km from Cabo Frio cape, on the east, to São Sebastião island, on its western limit (Figs. 1 and 4 ). This shelf has a gentle mean gradient of $\sim 0.04^{\circ}$ and becomes steeper offshore Sepetiba-I lha Grande bays $\left(\sim 0.07^{\circ}\right.$, Fig. $\left.4 f-h\right)$, where the shelf width reaches circa $125 \mathrm{~km}$ (Fig. 4f). In fact, the definition of shelf width and shelf break depth is not always easy to apply in this area, since shelfedge and upper slope morphologies are irregular due to the occurrence of strong erosional and/or gravitational collapse features (see below). Using the classical methods for determining the shelf break position and depth (e.g. Stanley and Moore, 1983), we found that it increases from $-160 \mathrm{~m}$ in the east, off Cabo Frio (Fig. 4a), to $-177 \mathrm{~m}$ in the west, off Ilha Grande bay (Fig. 4f). Off São Sebastião island, the shelf break at $-148 \mathrm{~m}$ is shallower again (Fig. 4h).

Two main NW-SE-oriented elongated depressions were mapped along the mid-outer continental shelf: the Eastern and the Western Corridors (Fig. 5). We define the mid-outer shelf as the portion of the continental shelf seaward of the 100-m isobath. The Western Corridor corresponds to a zone of deeper erosion $(\sim 30 \mathrm{~m})$, in comparison to the Eastern Corridor which shows a shallower erosion ( $\sim 15 \mathrm{~m}$; Figs. 4 and 5). A composite bathymetric and gradient map, drawn on the basis of the newly compiled bathymetric data, highlights the main geomorphic features that constitute the shelf seafloor morphology as well as their spatial variability (Fig. 6). At the regional scale, the $100-\mathrm{m}$ isobath marks a

271 clear transition between two contrasted landward and seaward shelf morphologies. 

and smooth morphology, whose front slope dips about $0.2^{\circ}$, along a $\sim 8-10 \mathrm{~km}$ wide zone bracketing the $100-\mathrm{m}$ isobath, forming a prominent sea-floor step (Figs. 4, 6 and 7). In map view, this wide zone forms a linear and continuous NESW-oriented bedform feature that draws away from the coastline westwards (Figs. 5 and 6), and exhibits distinct shapes in east-west orientation. Offshore of the Cabo Frio-Araruama lagoon region, the inner to mid shelf domain is defined by a continuous, slightly concave-up and rather steep sea-floor ramp $\left(\sim 0.255^{\circ}\right.$; Fig. 4b) whereas westwards, a convex-up profile draws a clear lobate shape on the sea-floor (Figs. 4c-d and 7). A succession of nine major lobate seabed features is also observed landward of the $100-\mathrm{m}$ isobaths (numbered 1 to 9 in Fig. 5). The features are elongated or semi-circular sediment bodies expressed by increased sea-floor gradient roughly coinciding with the $20 / 30,40 / 50 m$ and 60/70- $\mathrm{m}$ isobaths. The most distinguishable of these bathymetric steps are located on the western shelf, off Ilha Grande, Sepetiba and Guanabara bays (Figs. 4 and 5).

Seaward of the $100-\mathrm{m}$ isobath, the shelf gradient decreases to about $0.023^{\circ}-0.051^{\circ}$ (Figs. 4 and 6 ), and the seafloor is covered by an array of contour-parallel escarpments. These linear features form at least three escarpments of regional expression, roughly NE-SW-oriented, that run along the 110, $\sim 130$ and $\sim 150-\mathrm{m}$ isobaths. All the escarpments stand as fairly continuous contour line features when considering the $\sim 400 \mathrm{~km}$ lateral extent of the shelf. Nonetheless, they exhibit distinct relief, continuity and contour shapes in map view (Figs. 5 and 6): -Scarps at $-110 \mathrm{~m}$ are $\sim 5-8 \mathrm{~m}$ high, exhibit an average $0.2^{\circ}$ gradient, and are followed by wide and flat basal surfaces, as wide as $20 \mathrm{~km}$ (Figs. 6, 7 and $8 \mathrm{a}$ ). 
The linear escarpment tends to merge westwards with the $\sim 8-10 \mathrm{~km}$ wide zone bracketing the $100-\mathrm{m}$ isobath, forming one unique prominent sea-floor step (Fig. 5);

-Scarps at $-130 \mathrm{~m}$ are $\sim 10-20 \mathrm{~m}$ high, exhibit up to $0.4^{\circ}$ gradient, and are followed by a basal surface, $\sim 5-15 \mathrm{~km}$ wide (Figs. 6, 7 and 8 ). This escarpment draws the most sinuous trace on the modern bathymetry, showing some quite sinuous re-entrants, and disappears along segments of the Western shelf Corridor (Fig. 5);

-The distal -150 m escarpment follows a straighter feature closely to the bathymetric contour line, but occurs only along the main shelf-edge embayments (Fig. 5). This escarpment presents quite variable relative relief, ranging from a few meters to almost $60 \mathrm{~m}$, either being prolonged seaward by a basal flat surface, as wide as $\sim 5 \mathrm{~km}$, or grading into a larger seawardinclined erosive ramp presenting significant slopes of up to $\sim 0.75^{\circ}$ (Figs. 6 and 9). Along a few sectors of the two shelf-edge embayments, the escarpment is coupled with a highly erosive and deep basal channel incision tens of kilometers long, $\sim 8-10 \mathrm{~km}$ wide and $\sim 40-50 \mathrm{~m}$ deep, described for the first time in this study (Figs. 4 and 9c).

\subsection{Seismic and chronostratigraphic interpretation}

So far, in this paper we adopted a chronostratigraphy as had been established by Maia et al. (2010). However, the newly obtained high-resolution chirp seismic profiles revealed that shallow sequences Sq4 and Sq5 are stratigraphically more complex and exhibit a more distinctly lateral distribution than had been previously recognized. Moreover, the combination of bathymetric 
data and seismic profiling illustrates the various morphologies and stacking patterns related to the Latest Quaternary history of the shelf sedimentary system.

\subsubsection{Refined stratigraphic architecture of sequence Sq4}

On the inner to middle shelf, sequence $\mathrm{Sq} 4$ can build up lobate depositional units, with an estimated thickness of circa 20-25 m. As a general pattern, this wedge is composed of the stacking of at least two seismically transparent units (sub-units Sq4a and Sq4b; Fig. 7). Reflections at the distal end of these units show clinoforms, suggesting progradation (e.g. Mitchum et al., 1977b). Erosive surfaces constitute the top limits of the upper and lower seismic sub-units Sq4a and Sq4b (surfaces S5 and S5', respectively) depicting incisions that on average are up to $10 \mathrm{~m}$ deep and $\sim 50 \mathrm{~m}$ wide, with local evidence of developed incised valleys (Fig. 7). According to its position along the depositional profile, seismic facies and overall backstepping stacking pattern, we interpret this proximal wedge as representing vertical sediment accumulation formed during transgression (transparent facies), interrupted by a sea-level drop and partial lowstand shelf exposure (unconformities $\mathrm{S} 5$ ' and $\mathrm{S} 5$ followed by distal clinoforms).

Given the tectonic stability of the RJ margin over the Late PleistoceneHolocene period and its tropical location away from glaciations (e.g. Chang et al., 1992; Cainnelli and Mohriak, 1999), we used global eustatic sea-level curves (Fig. 10) in order to bring some paleobathymetrical-chronological constraints to our uppermost stratigraphic units. The interpretation of seismic sub-units Sq4a and Sq4b in the light of independent sea-level curves suggest them to result from oscillations in the course of the Late Pleistocene sea-level fall. The 
elevations of sub-units Sq4a and Sq4b along the depositional profile make us interpret them to have formed during Marine Isotope Substages 5e-5a and MIS 4, when sea level fell from a few meters above to circa $100 \mathrm{~m}$ below present sea level, with considerable intermediate oscillations (Figs. 7 and 10a). As such, this proximal composite sedimentary wedge, in spite of representing gradual Late Pleistocene sea-level lowering, may be interpreted as a late Highstand Systems Tract (IHST; Catuneanu, 2006), that is topped by a surface formed by forcedregression. Seawards, this composite lobate wedge grades into higher angle parallel-oblique prograding clinoforms, reflecting the offlapping forced-regressive wedges that extend as far as the distal end of the shelf break. These offlapping wedges are the dominant stratigraphic elements of a Falling-Stage Systems Tract (FSST; Plint and Nummedal, 2000), presumably formed during MIS 3 and MIS 2 (Figs. 7 and 10).

The new dataset also shows that the earlier interpretation of $\mathrm{Sq} 4$ as a continuous sequence across the entire mid-outer shelf was too simplistic. Sq4 is somewhat eroded in the Eastern Corridor, and deeply or totally eroded in the Western Corridor, where neither a proximal Sq4 HST, nor distal FSST deposition is well preserved. On the other hand, evidence for associated incised valleys is widespread (Figs. 11 and 12). In addition, seismic profiles also revealed a spatial relationship between the shelf corridors as zones of enhanced erosion, and the sinuosity and lateral continuity of the $-110 \mathrm{~m}$ and $-130 \mathrm{~m}$ escarpments. Within the Eastern Corridor, the $-110 \mathrm{~m}$ and $-130 \mathrm{~m}$ escarpments tend to present a more sinuous trace, whereas within the Western Corridor these both escarpments are missing (Figs. 5 and 12). We associate the enhanced erosion in the shelf corridors with increased fluvial incision, that gradually propagated upstream from the shoreline in order to balance the increasing base-level lowering, thus leading to the escarpments' trace retreat. In the Western Corridor, 
Sq4 has been so deeply eroded that S5 merges with S4 into a single, flatter unconformity erosional surface (Figs. 11 and 12). Enhanced erosion within the Western Corridor is also seismically indicated by a cyclical pattern of fluvial incision-infilling that repeats through time on both surfaces S5 and S4, as widespread features extending from the inner to the outer shelf (Fig. 12). Increased erosion within this shelf corridor can explain the local removal of sequence $\mathrm{Sq} 4$, the flattening morphology of the merging surfaces S4-S5 as well as the absence of the $-110 \mathrm{~m}$ and $-130 \mathrm{~m}$ escarpments (Figs. 11 and 12).

\subsubsection{Refined stratigraphic architecture of the uppermost sequence Sq5}

We here present a revised architectural interpretation of sequence Sq5 of Maia et al. (2010). The high-resolution chirp seismic lines show that this youngest sedimentary unit covers the entire shelf landward of the $150 \mathrm{~m}$ deep escarpment as a tabular unit, whereas towards the shelf edge, the seabed consists exclusively of older S4 regressive wedges (Figs. 7 and 12). This means that the basal surface $\mathrm{S} 5$ does not represent the modern seafloor along its entire extent, unlike previously proposed (Fig. 3), but rather is a somewhat older erosional horizon with several steps and seaward dip: S5 represents the last lowstand exposure surface. It is overlain by the Sq5 deposits, observed widespread throughout the shelf (Fig. 7). The stratigraphic position of this top sedimentary unit supports the interpretation of it as being the product of latest Pleistocene-Holocene gradual deposition that began when the last deglaciation began, i.e. not solely as Holocene deposition.

The seismic data do not show clear internal patterns within the tabular Sq5 sedimentary units across the mid-outer shelf. Instead, the unit appears acoustically transparent, and was thus interpreted as a transgressive siliciclastic 
sheet (Figs. 8, 11 and 12). Its thickness is however highly variable across the shelf. Relative thicker deposition (up to $\sim 15 \mathrm{~m}$ ) is observed throughout the western shelf sector, encompassing the Western Corridor and the adjacent shelf, where it fills depressions in the underlying S5 erosional surface (Fig. 11). Widespread fluvial incision-infilling patterns, seismically recognized on the western shelf sector in Sq4 and the thicker Sq5, indicate relatively higher sediment supply to this sector after the LGM (Fig. 12).

On the inner shelf, Sq5 sedimentation to some degree has piled up as prism-like depositional features, maximizing at 8-10 m thickness only locally (Fig. 5). In the central shelf sector, this sedimentary unit is composed of frontal progradational foresets with no clear seismic evidence of significant erosion (Fig. 13b). Sparse coverage and limited resolution of seismic data makes it difficult to further detail the internal architecture of these features. Nevertheless, the most distinguishable of these prism-like features are located off Guanabara bay where they form major semi-circular bathymetric steps, that roughly coincide with the $\sim 20, \sim 30$ and $\sim 40-\mathrm{m}$ isobaths (numbered 1 to 3 in Fig. 5). In the western shelf sector, the prisms pile up as backstepping transparent depositional units with smaller-scale rough morphology; a few of them have smooth bathymetric bulges at their distal ends (Figs. 13c). This generates elongated and laterallydiscontinuous higher-gradient steps on the sea-floor slope, that locally coincide with the $\sim 50, \sim 60$ and $\sim 70-\mathrm{m}$ isobaths (numbered 4 to 9 in Fig. 5).

The entire seafloor morphology seaward of the $100-\mathrm{m}$ isobath is also affected by relatively high frequency rugged relief superimposed on the scarpterraces previously described (Figs. 7, 9, 11 and 12). This micro relief is ascribed to the occurrence of the bioconstructional forms, as have been previously reported for the study area (Milliman, 1978; Figueiredo and Tessler, 2004). On higher-resolution seismic lines these features appear to be up to $\sim 10 \mathrm{~m}$ thick, 
and relative large areas of the sea-floor are covered with these carbonate buildups. In places they clearly overly clastic transgressive Sq5 facies (Fig. 14), which makes these bioconstructions part of the Sq5 HST.

\section{DISCUSSION}

From various siliciclastic continental shelf settings around the world, studies provide examples of seafloor geomorphologies affected by the last transgression, with the youngest transgressional features identified as purely depositional, or purely erosional or a composite of both (e. g. Emery and Uchupi, 1984; Milliman et al., 1990; Correa, 1996; Duncan et al., 2000; Lobo et al., 2004; Bassetti et al., 2006; Berné et al., 2007; Schattner et al., 2010). In such studies, typically based primarily on high-resolution seismic stratigraphy and occasional drill holes, linear stepped shelf bathymetric features are often tied to periods of decelerated sea-level rise or stillstands during the last transgression. Those shelves are either sediment-starved, such as the New Jersey shelf (e.g. Duncan et al., 2000), or are under high sediment input, such as the submerged Rhône deltaic system (e.g. Berné et al., 2007). A recent review and synthesis of transgressive deposit types is presented by Cattaneo and Steel (2003).

Despite the current controversy over the exact sea-level position at the LGM (a fall as modest as $-90 \mathrm{~m}$ or as deep as $-140 \mathrm{~m}$ ), global sea-level data based on independent proxies and modelled reconstruction, from the end of the LGM onwards indicate global sea levels to have risen dramatically: fast and by a great amount, but non-uniformly (e.g. Fairbanks, 1989; Bard et al., 1990; Bard et al., 1996; Lambeck and Bard, 2000; Lambeck et al., 2002; Lambeck et al., 2004; Clark, 2009; Berné et al., 2007; Bard et al., 2010). The first order rate of sea-level rise averaged over the entire deglaciation ( $20 \mathrm{ka}$ to present) is around $5-6 \mathrm{~m} / \mathrm{kyr}$. But this deglaciation is known to have been characterized by 
two or three periods of increased rates of rise, including so-called Melt Water Pulses, separating periods of much lower rates (Fairbanks, 1989; Bard et al., 1990). The sea level for the latter periods would be indicated by elevation steps at sea levels $\sim 100, \sim 60$ and $\sim 40 \mathrm{~m}$ below present, the last one overstepped by sea-level rise acceleration at the beginning of the Holocene (Fig. 10b). However, in our combined seismic and geomorphological interpretation, transgressive morphological features from the shorter period of sea-level rise in the last $\sim 20 \mathrm{ka}$ are very scarce and limited to the present inner-shelf, where they appear as laterally-discontinuous depositional prisms forming local bathymetric steps. Our seismic analysis and timing deductions indicate that the linear, stepped bathymetric features have the same spatially relation across the entire shelf and link to a set of architectural elements that developed over the much longer lasting phase of Late Pleistocene sea-level lowering, regression and shelf exposure towards the LGM, i.e. between $\sim 120$ and $\sim 20$ ka (Fig. 15). On the outer shelf, transgressive and highstand deposits are limited to a thin veneer of reworked material and coral carbonate bioconstructions with a distinct transparent chirp facies (Figs. 7 and 11).

5.1 Geomorphic indicators attributable to stratigraphic elements and dynamic processes of the Late Pleistocene regression ( 120 to 20 ka)

In spite of the blanketing presence of Sq5 deposition, a prominent regional-scale sea-floor step that brackets the 70-100 $\mathrm{m}$ isobaths stand out in the modern bathymetry (Figs. 5 and 6). It is the morphological expression of the spatial discontinuity and stratigraphic gap between the proximal and the distal stratigraphic elements of last completed sequence Sq4, formed over the $\sim 100$ kyr of the Late Pleistocene. From this sequence Sq4, a partially preserved HST remains proximal on the shelf, and a distal FSST remains down-dip (section 
16, we related this stratigraphic gap to the eustatic sea-level regressive scenario between MIS 5e and MIS 2 (Late Pleistocene): (A) At to (MIS 5d) the depositional profile of shelf sediments consists of forced-regressive Sq3 wedges, previously deposited during stages of falling sea level between MIS 7 and MIS 6, while the shoreline is on the middle shelf off southern Rio de Janeiro State. Sea level rises rapidly between to and $t 1$ (MIS 5c) resulting in the deposition of transgressive prisms on the inner shelf; (B) sea level drops between MIS $5 \mathrm{c}$ and MIS 5b (t2) and induces erosion on the shelf that partially reworks the previously deposited transgressive prism, while further on the outer shelf a new prism forms. The final sedimentary motif is a composite transgressive-prograding clinoform preserved as sub-unit Sq4a. Unconformity S5' thus reflects the shelf's partial exposure at $t 2$; $(C)$ sea level then rises rapidly again between $t 2$ and $t 3$ (MIS 5a) and then (D) drops towards t4 (MIS 4), inducing vertical accumulation of a second composite transgressive-regressive wedge (subunit Sq4b). The ensuing regressive sea-level trend between $t 4$ and $t 6$ ( $E$ and $F$ ) partially erases the previous sediment accumulation, leading to the deposition of offlapping forced-regressive Sq4 wedges that extend as far as the distal end of the shelf break (a FSST). We interpret this erosional gap and the observed change of dip in surface S5, as indicating the outpacing of the relatively low rate of sediment influx (which characterizes this shelf; Milliman, 1978; Rocha et al., 1975), by the ongoing sea-level fall and the steadily accelerating base-level lowering from MIS 3 to MIS 2 (Fig. 10a). An outpaced sediment flux can explain, at least in part, the stratigraphic discontinuity between highstand and regressive deposits in the down-dip direction. Nonetheless, Sq4 forced-regressive wedges did preserve on the outer shelf, showing that the sediment flux was sufficient to fill some accommodation space on the shelf, i.e. that progradation kept up with rates of sea-level fall (Figs. 3 and 7). 
513 data from which sedimentation and sea-level variation could be reconstructed, 514 not for the Late Pleistocene and not for the post-LGM. Still, based on the envelope of the compiled global sea-level data (the maximum variability interval; Fig. 10a), we reckon that the partial preservation of the HST of sequence Sq4 is due to the fact that MIS $5 e$ was represented by a relatively high sea-level position (meters above current sea level) compared to highstands before and after (Fig. 10a), whereas the lowstand in the LGM is generally considered to have been at a shallower level, and lasted less long, than the penultimate lowstand (the MIS 6 glacial maximum; Fig. 10a). Such offset between subsequent cycles can possibly explain why part of Sq4 represents late HST deposits (Fig. 8).

Throughout the study area, the appearance of the Sq4 proximal wedge varies considerably in the across shelf direction, probably due to variable sediment supply. In the eastern shelf domain, its thickness does not exceed $\sim 8$ $\mathrm{m}$ and prograding units are absent, resulting in a continuous and slightly concave-up sea-floor profile. Therefore, this depositional wedge, although marking a transition in the sea-floor slope around the $100-\mathrm{m}$ isobath, does not seem to have impacted the modern sea-floor morphology across this shelf sector (Fig. 13a). On the central-western shelf, where substantially larger sediment supply reached areas off the Guanabara, Sepetiba and I lha Grande bays, sets of internal acoustic facies are quite distinct: composed of thicker transparent series with developed prograding foresets and deeply incised valleys (Fig. 13b). This composite prograding wedge generated a prominent convex-up seafloor bathymetry forming the step-like bedform that appears as a continuous morphological feature along the $100-\mathrm{m}$ isobath, extending over $250 \mathrm{~km}$ in an E-

537 W direction in the central and western shelf domains of the study area (Fig. 15). 
Another outstanding morphological signature of sequence Sq4 is the

539 offlapping seaward-downstepping character of its distal stratigraphic elements,

540 forming detached forced-regressive wedges that became gradually deeper and

541 younger spreading over $40-60 \mathrm{~km}$ towards the shelf break (section 4.2.1; Figs. 7

542 and 8). The combined seismic and morphological analyses allowed to spatially 543 associate the fairly continuous $-110 \mathrm{~m}$ linear escarpment and its coupled seaward-dipping terrace, to an erosional remnant of offlapping shorelines still preserved in the modern shelf morphology. Accordingly, we associated its -5-10 m relief with a sort of footprint of detached downstepping wedges formed during the Late Pleistocene sea-level fall, with little reworking and marine obliteration during the subsequent rapid transgression. Considering the seismic resolution of the available dataset, the $-110 \mathrm{~m}$ escarpment appears then as a purely erosional inclined feature on the modern bathymetry, while the associated basal seaward-stepping terrace sculpted on surface S5 is all over capped by a transgressive Sq5 sediment layer (Figs. 7 and 15).

In the light of the available eustatic sea-level curves, we speculate that such downstepping forced-regressive morphology observed on the mid-outer shelf probably formed at $t 5$, the inflection point of the regressive curve, explained by accelerating sea-level fall during MIS 3 and into MIS 2 (Fig. 16 E and F). In fact, it is worth noting that similar erosional remnants imprint seaward subaerial exposure surfaces S4 and S3 (respectively, top and basal boundary of sequence $\mathrm{Sq} 3$ ) and also draw steps of the order of a few meters high towards their respective palaeo-shelf breaks. This cyclical pattern of seaward downstepping terraces actually shows that they are recurrent geomorphic features developed during $\sim 100 \mathrm{kyr}$ long lasting periods of successive sea-level lowstands and shelf exposure of the continental shelf of the study area (Fig. 3). 
5.2 Geomorphic indicators attributable to stratigraphic elements and dynamic processes at the LGM ( 20 kyr)

As shown in section 4, the most distinguishable continuous relief feature mapped across the continental shelf off southern RJ is the modern bathymetric footprint of the boundary surface S5 (Figs. 7 and 8), that in earlier studies had been interpreted as a prominent shelf-wide unconformity (Maia et al., 2010). High resolution seismic reflection profiles interpreted for this study also showed that S5 truncates the underlying units but with distinct patterns of erosion. Landward of the $130-\mathrm{m}$ isobath, S5 is a smooth downstepping and seaward dipping surface capped by younger Sq5 seismic strata. Seaward of the 130-m isobath, S5 shows more pronounced erosion and limited Sq5 cover (Figs. 7 and 8). In spite of the total absence of direct measurements and datings in the study area, we suggest that the linear scarp mapped around the $-130 \mathrm{~m}$ contour line is the regional geomorphic indicator of the LGM sea-level position (At $t 6$ in Fig. 16 F). Wave-cut erosion must be evoked for the generation of such an outstanding morphological feature, compatible with prolonged wave action during a stillstand (Fig. 8). As a consequence, we no longer interpret S5 as an exposure surface across its whole extent. Landward of the 130-m isobath S5 would have been a subaerial surface whereas seaward of this depth it would have been a purely marine surface (Figs. 8 and 15). Finally, we note that the Sq5 transgressive layer and carbonate bioconstructions can add up to $10 \mathrm{~m}$ to the scarp's total relative relief thus enhancing the scarp (Figs. 8 and 14).

5.3 Geomorphic indicators attributable to stratigraphic elements and dynamic processes of the post-LGM transgression (last 20 kyr)

The $-150 \mathrm{~m}$ escarpment expresses itself as a morphological feature linked to the youngest distal shelf clinoform, at around 20-30 m below the basal terrace of the -130 m escarpment (Fig. 8b). Seismic data show a large shelf edge zone 
593 affected by intense bottom erosion with exposure of relict strata seaward of the 594 150-m isobath down to the offshore limit of the available seismic imagery, 595 beyond the 250-m depth contour (Figs. 7, 8, 9 and 12). In contrast with the $596-130 \mathrm{~m}$ scarp, this deeper escarpment in the distal zone of major shelf-edge 597 erosion is attributed to marine erosion that is unrelated to wave action. We 598 interpret its formation to be associated with landward displacement and 599 enhanced bottom erosion of the southward flowing BC, during the last 600 transgression (Figs. 8 and 16 F). This would be in accordance with studies 601 carried out by Nagai et al. (2010), that integrated sedimentological, geochemical and microfaunal proxies, as well as with a conceptual model proposed by Mahiques et al. (2007). This means that the -150-m escarpment along the two large shelf-edge embayments described in section 4.1 (Figs. 9 and 15), as well as its associated basal channels, are seen as post-LGM features. Previous studies have proposed that exposure of relict Pleistocene facies at shallower bathymetric levels equivalent to the mid-shelf (i.e. the $\sim 130$-m isobath) was due to a "floorpolisher" effect of the meandering BC main flow (Mahiques et al., 2002; Mahiques et al., 2010). Although we do consider such a sculpturing role for the shelf edge, our architectural seismic analysis revealed the presence of a continuous tabular Sq5 transgressive layer throughout the entire mid-outer shelf, implying that it was not significant on the mid-shelf. Laterally-discontinuous stepped bedforms located on the inner shelf landward of the 100-m isobath are also interpreted as geomorphic indicators of stratigraphic elements of the post-LGM transgression. However, while previous studies describe inner-shelf stepped features as probably representing stillstand 617 shores (Zembruscki, 1979; Corrêa et al., 1980) and thus as being, at least partially, erosional in nature, the new seismic evidence shows that, on the contrary, they may be fully depositional features. In the central shelf sector, off 
620 Guanabara Bay, the mapped bedforms are essentially depositional Sq5 prism-like 621 sediment bodies, exhibiting external lobate shapes that suggest progradational 622 bedforms that roughly coincide with the 20,30 and $40-\mathrm{m}$ isobaths (Figs. 5, 13 623 and 15). Limited seismic resolution and the absence of direct sampling and 624 dating make it impossible to explain the construction of these features or to 625 establish their exact eustatic position during the post-LGM transgression. They 626 may represent the preservation of shorelines and shorefaces that had developed 627 during periods of relatively slower sea-level rise in the Early Holocene, around the present-day $30-40 \mathrm{~m}$ isobath (Fig. 9b). We can equally speculate that they correspond to subaqueous deposition on the inner-shelf during highstand scenarios thus representing infra-littoral prisms (sensu Hernandez-Molina et al, 2000; Fernández-Salas et al., 2009) as, for instance, the modern features developed at the mouth of Guanabara Bay (probably under the influence of strong tidal currents). In the western shelf sector, on the other hand, Sq5 is mostly composed of transparent seismic units stacked in backstepping fashion, and 15).

5.4 Pleistocene sediment supply to the shelf

This seismic stratigraphic framework points thus to an effective sediment supply to the shelf basin during most of the time in the Late Pleistocene, a scenario that contrasts with the current idea of dominantly sediment-starved Late Pleistocene shelves. Our results naturally raise questions about the nature and origin of the sediment supply, since nowadays no significant siliciclastic 
646 fluvial point source flows directly into the shelf. We are led to speculate about a 647 more important participation of secondary drainage basins that presently 648 debouch directly into partially-enclosed coastal environments, like the Guanabara 649 and Sepetiba bays, to have supplied sediment to the adjacent shelf (as recently 650 pointed out by Friederichs et al.; in press); we may also have to consider the 651 possible role of neotectonic movements involving the Serra do Mar coastal 652 mountain ranges that, at times, might have been the source of the clastic influx 653 into the basin during the Quaternary.

\section{CONCLUSIONS}

Our paper addresses the bathymetric and seismic mapping of Upper

Pleistocene submerged geomorphological elements and the origin of encountered linear, stepped features observed along the continental shelf off southern Rio de Janeiro state, northern Santos basin. Newly obtained high resolution seismic reflection records (down to about 100 ms penetration below sea-floor), revealed the higher-resolution stratigraphic organization of shelf sedimentary systems, telling the shelf's history since MIS 5. Even in the absence of independent biostratigraphical or numerical ages, the analysis allows to identify features associated to youngest sea-level falls from those formed during youngest sealevel rise. Because the study area is a far-field tropical shelf, global eustatic sea-

667 level curves then provide chronological constraints for transgressive and 668 regressive features in known order at known depths. inner shelf, it comprises of proximal lobate depositional units (as thick as $\sim 20-25$ $\mathrm{m})$, that grade into prograding clinoforms, extending as far as the distal end of 
672 the shelf break as offlapping forced-regressive wedges with vertical sediment 673 accumulation as thick as $\sim 40-50 \mathrm{~m}$. This sequence stopped accumulated when 674 the shelf was exposed during the lowstand of the LGM (ca. 25-20 ka). Following 675 the LGM, transgressive sedimentation (Unit Sq5, up to $\sim 15 \mathrm{~m}$ thick) has blanketed the continental shelf landward of an escarpment at $150 \mathrm{~m}$ depth. across the continental shelf off southern Rio de Janeiro State are actually of Late Pleistocene age, formed under regressive conditions, with some sediment supply.

Present-day conspicuous bathymetric steps mapped at $-110,-130$ and $-150 m$ have diverse geomorphic features and were related to the sea-level variations spanning the last interglacial-glacial-interglacial cycle. The $-110 \mathrm{~m}$ escarpment is an erosional imprint of offlapping stepped forced-regressive wedges that were probably sculpted between MIS 3 and MIS 2. The $-130 \mathrm{~m}$ escarpment relates to the shoreline position during the LGM. As for the $-150 \mathrm{~m}$ scarp, we suggest this to be formed in response to shelfward migration of the Brazil Current, accompanying the sea-level rise during the last transgression. Transgressive and highstand morphological imprints of the rapid sea-level rise of the post-LGM (youngest $\sim 20 \mathrm{kyr}$ ) are extremely scarce and limited to the current inner-shelf only, where they appear as laterally-discontinuous depositional prisms forming local bathymetric steps offshore Guanabara, Sepetiba and Ilha Grande bays, through which a substantially large sediment supply reached the drowning shelf.

\section{ACKNOWLEDGEMENTS}

This research was funded by a program of concerted action between the

Brazilian Ministery of Science, Technology and Innovation (MCTI) and the 
698 through the availability of ship time. The study was also partially funded by

699 CAPES (Coordination for the Improvement of Higher Level Education, "Ciências 700 do Mar", grant 23038.051609/2009-61), FAPERJ-Research Agency of Rio de 701 Janeiro State (grants 110.812/2008, 111.516/2008, 110.161/2009, $702101.519 / 2009$ and 102.254/2009) and CNPq-the Brazilian National Research 703 Agency (Universal grant 474004/2010-4). This work further benefited from a 704 State Grant from the French "Agence Nationale de la Recherche (ANR)" in the 705 Program "Investissements d'Avenir" (ANR-10-LABX-19-01, Labex Mer), and 706 international research grants by Institut Universitaire des Sciences de la Mer 707 (IUEM) and Université de Bretagne Occidental (UBO), France. The authors gratefully acknowledge the contribution of the captain and crew of $R / V$ Cruzeiro do Sul in the acquisition of seismic data during leg 2 of RIO COSTA 1 Cruise (August 2010). We thank the CHM-Centro Hidrográfico da Marinha do Brasil for sharing their bathymetric database. Special thanks are due to Seismic Micro-Technology Inc. (SMT) for the use of educational licenses of the software Kingdom Suite ${ }^{\circledR}$ and CNPq for the research grants conceded to the first and third authors, and scholarships to undergraduate students (PIBIC/CNPq). We are grateful to two anonymous reviewers for significantly improving the work with their insightful comments. We also thank the Editor Kim Cohen for constructive suggestions and constant support to this paper. This is a contribution of the research group GEOMARGEM-Geology and Oceanography of Passive Continental Margins (http://www.geomargem.org).

\section{REFERENCES}

Alves, M.A., 1992, Correntes de maré e inerciais na plataforma continental ao largo de Ubatuba (SP). Master Dissertation, Instituto Oceanográfico da Universidade de São Paulo (USP), 162 pp. São Paulo, Brazil (in Portuguese). 
Bard, E., Hamelin, B., Fairbanks, R.G., 1990. U-Th ages obtained by mass spectrometry in corals from Barbados: sea level during the past 130,000 years. Nature 346, 456-458.

Bard, E., Hamelin, B., Arnold, M., Montaggioni, L., Cabioch, G., Faure, G., Rougerie, F., 1996. Deglacial sea-level record from Tahiti corals and the timing of global meltwater discharge. Nature 382, 241-244.

Bard, E., Hamelin, B., Delanghe-Sabatier, D., 2010. Deglacial Meltwater Pulse 1B and Younger Dryas Sea Levels Revisited with Boreholes at Tahiti. Science $327,1235-1237$.

Bassetti, M.A., Jouet, G., Dufois, F., Berne, S., Rabineau, M., Taviani, M., 2006. Sand bodies at the shelf edge in the Gulf of Lions (western Mediterranean): deglacial history and modern processes. Marine Geology, 234, 93-109.

Bassinot, F., Labeyrie, L., Vincent, E., Quidelleur, X., Lancelot, N.J., Lancelot, Y., 1994. The astronomical theory of climate and the age of the BrunhesMatuyama magnetic reversal. Earth and Planetary Sciences Letters 126, 91108.

Berné, S., J ouet, G., Bassetti, M.A., Dennielou, B., Taviani, M., 2007. Late Glacial to Preboreal sea-level rise recorded by the Rhône deltaic system (NW Mediterranean). Marine Geology 245, 65-88.

Cainnelli, C., Mohriak, W.U., 1999. Some remarks on the evolution of sedimentary basins along the eastern Brazilian continental margin. Episodes 22, 206-216.

Calado, L., da Silveira, I.C.A., Gangopadhyay, A., de Castro, B.M. 2010. Eddyinduced upwelling off Cape São Tomé (22 degrees S, Brazil). Continental Shelf Research 30, 1181-1188.

Campos, E., Velhote, D., Silveira, I.C., 2000. Shelf-break upwelling driven by Brazil Current cyclonic meanders. Geophysical Research Letters 27, 751-754.

Cattaneo, A., Steel, R.J.T., 2003. Transgressive deposits: a review of their variability. Earth-Science Reviews 62, 187-228.

Catuneanu, O., 2006. Principles of Sequence Stratigraphy. Ed. Elsevier, 375 pp.

Chang, H.K., Kowsmann, R.O., Figueiredo, A.M.F., Bender, A., 1992. Tectonics and Stratigraphy of the East Brazil Rift System: an Overview. Tectonophysics 213, 97-138.

Clark, P.U., 2009. Ice sheet retreat and sea level rise during the last deglaciation. PAGES News 17, 64-66. 
Chappell, J., Shackleton, N.J. 1986. Oxygen isotopes and sea level. Nature 324, 137-140.

Corrêa, I.C.S., Ponzi, V.R.A., Trindade, L.A.F., 1980. Níveis marinhos quaternários da plataforma continental do Rio de Janeiro. XXXI Cong. Bras. Geologia, pp. 578-587 (in Portuguese).

Correa, I.C.S., 1996. Les variations du niveau de la mer durant les dreniers 17.500 ans BP: l'exemple de la plate-forme continentale du Rio Grande do Sul - Brésil. Marine Geology 130, 163-178 (in French).

Costa, M.P.A., Alves, E.C., Pacheco, P.G., Maia, A.S., 1988. Prováveis estabilizações do nível do mar holocênico em trechos da plataforma continental entre o norte de São Paulo e o sul do Rio de Janeiro, constatadas através de morfologia de detalhe. XXXV Cong. Bras. Geologia, pp. 436-450 (in Portuguese).

Cutler, K.B., Edwards, R.L., Taylor, F.W., Cheng, H., Adkins, J., Gallup, C.D., Cutler, P.M., Burr, G.S., Bloom, A.L., 2003. Rapid sea-level fall and deep ocean temperature change since the last interglacial period. Earth and Planetary Science Letters 206, 253-271.

Duarte, C.S.L., Viana, A.R., 2007, Santos drift system: stratigraphic organization and implications for late Cenozoic palaeocirculation in the Santos Basin, SW Atlantic Ocean. In: Viana, A.R., Rebesco, M. (Eds.), Economic and palaeoceanographic significance of contourite deposits. Geological Society of London Special Publications 276, 171-198.

Duncan, C.S., Goffa, J.A., Austin J r, J.A., Fulthorpe, C.S., 2000. Tracking the last sea-level cycle: sea-floor morphology and shallow stratigraphy of the latest Quaternary New Jersey middle continental shelf. Marine Geology 170, 395421.

Emery, K.O., Uchupi, E., 1984. The Geology of the Atlantic Ocean. Springer, New York, $1050 \mathrm{pp}$.

Fairbanks, R.G., 1989. A 17,000-year glacio-eustatic sea level record: influence of glacial melting dates on the Younger Dryas event and deep-ocean circulation. Nature 342, 637-642.

Fernández-Salas, L.M., Dabrio, C.J., Goy, J.L., Díaz Del Río, V., Zazo, C., Lobo, F.J., Sanz, J.L., Lario, J., 2009. Land-sea correlation between Late Holocene coastal and infralittoral deposits in the SE Iberian Peninsula (Western Mediterranean). Geomorphology 104, 4-11. 
Figueiredo Jr, A.G., Tessler, M.G., 2004. Topografia e composição do substrato marinho da Região Sudeste-Sul do Brasil. Technical Report, Instituto Oceanográfico (USP). Série Documentos Revizee - Score Sul, 64 pp. São Paulo, Brazil (in Portuguese).

Friederichs, Y.L., Reis, A.T., Silva, C.G., Toulemonde, B., Maia, R.M.C, Guerra, J.V., in press. The seismic architecture of the Sepetiba fluvio-estuarine system preserved on the shallow stratigraphic record on the offshore innermid shelf, Rio de Janeiro, Brazil. Revista Brasileira de Geociências (in Portuguese).

Hernandez-Molina, F.J., Fernandéz-Salas, L.M., Lobo, F.J., Somoza, L., Díaz Del Río, V., Alveirinho Dias, J.M., 2000. The infralittoral prograding wedge: a new large-scale progradational sedimentary body in shallow marine environments. Geo-Marine Letters 20, 109-117.

Imbrie, J., Hays, J.D., Martinson, D.G., Mclntyre, A., Mix, A.C., Morley, J.J., Pisias, N.G., Prell, W.L., Shackleton, N.J., 1984. The orbital theory of Pleistocene climate: support from a revised chronology of the marine $\delta 018$ record. In: Berger, A., Imbrie, J., Hays, J., Kukla, G., Saltzman, B. (Eds.), Milankovitch and climate. Reidel Publishing Company, Dordrecht, pp. 269305.

Kowsmann, R.O., Costa, M.P.A., Vicalvi, M.A., Coutinho, M.G.M., Gamboa, L.A.P., 1977. Modelo da sedimentação holocênica na plataforma continental sul brasileira. In: Projeto REMAC - Evolução sedimentar holocênica da plataforma continental e do talude do Sul do Brasil. Série Projeto REMAC, PETROBRAS, CENPES-DINTEP, 2, pp. 7-26 (in Portuguese).

Kowsmann, R., Vicalvi, M., Costa, M., 1979. Considerações sobre a sedimentação quaternária na plataforma continental entre Cabo Frio e o rio Itabapoana. Notícia Geomorfológica 19 (37-38), 41-58 (in Portuguese).

Kowsmann, R.O., Costa, M.O.A., 1979. Sedimentação quaternária da margem continental brasileira e das áreas oceânicas adjacentes. Série Projeto REMAC, PETROBRAS, CENPES-DINTEP Petrobrás, Rio de Janeiro, 55 pp (in Portuguese).

Labeyrie, L.D., Duplessy, J.C., Blanc, P.L., 1987. Variations in mode of formation and temperature of oceanic deep waters over the past 125.000 years. Nature 327, 477-482. 
Lambeck, K., 1997. Sea-level change along the French Atlantic and Channel coasts since the time of the Last Glacial Maximum. Palaeogeography. Palaeoclimatology and Palaeoecology 129, 1-22.

Lambeck, K., Bard, E., 2000. Sea-level change along the French Mediterranean coast from the past 30000 years. Earth and Planetary Science Letters 175, 203-222.

Lambeck, K., Chappell, J., 2001. Sea level change through the Last Glacial Cycle. Science 292, 679-686.

Lambeck, K., Yokoyama, Y., Purcell, A., 2002. Into and out of the Last Glacial Maximum: sea-level change during the Oxygen Isotope 3 and 2. Quaternary Science Reviews 21, 343-360.

Lambeck, K., Antonioli, F., Purcell, A., Silenzi, S., 2004. Sea-level change along the Italian coast for the past 10,000 yr. Quaternary Science Reviews 23, 1567-1598.

Lobo, F.J., Sánchez, R., González, R., Dias, J.M.A., Hernández-Molina, F.J., Fernández-Salas, L.M., Díaz del Río, V., Mendes, I., 2004. Contrasting styles of the Holocene highstand sedimentation and sediment dispersal systems in the northern shelf of the Gulf of Cadiz. Continental Shelf Research 24, 461-482.

Mahiques, M.M, da Silveira, I.C.A., Sousa, S.H.M., Rodrigues, M., 2002. PostLGM sedimentation on the outer shelf-upper slope of the northernmost part of the São Paulo Bight, southeastern Brazil. Marine Geology 181, 387-400.

Mahiques, M.M, Tessler, M.G, Ciotti, A.M, Silveira, I.C.A., Sousa, S.H.M., Figueira, R.C.L, Tassinari, C.C.G., Furtado, V.V., Passos, R.F., 2004. Hydrodynamically driven patterns of recent sedimentation in the shelf and upper slope off Southeast Brazil. Continental Shelf Research 24, 1685-1697.

Mahiques, M.M, Bícego, M.C, Silveira, I.C.A, Sousa, S.H.M., Lourenço, R.A., Fukumoto, M.M., 2005. Modern sedimentation in the Cabo Frio upwelling system, Southeastern Brazilian shelf. Anais da Academia Brasileira de Ciências 77, 535-548.

Mahiques, M. M.; Fukumoto, M. M.; Silveira, I. C. A.; Figueira, R. C. L.; Bícego, M. C.; Lourenço, R.A.; Sousa, S.H.M., 2007. Sedimentary changes on the Southeastern Brazilian upper slope during the last 35000 years. Anais da Academia Brasileira de Ciências 79, 171-181.

Mahiques, M.M., Mello e Sousa, S.H., Furtado, V. V., Tessler, M.G., Toledo, F.A.L., Burone, L., Figueira, R.C.L., Klein, D.A., Martins, C. C., Alves, 
D.P.V., 2010. The Southern Brazilian shelf: general characteristics, quaternary evolution and sediment distribution. Brazilian Journal of Oceanography 58 (no.spe2), 25-34.

Maia, R.M.C., Reis, A.T., Alves, E.C., Silva, C.G., Guerra, J.V., Gorini, C., Silva, A., Arantes-Oliveira, R., 2010. Architecture and stratigraphic framework of shelf sedimentary systems off Rio de Janeiro state, northern Santos basinBrazil. Brazilian J ournal of Oceanography 58 (no.spe2), 15-29.

Milliman, J.D., 1978. Morphology and structure of the upper continental margin of Southern Brazil. Bulletin of the American Association of Petroleum Geologists 62, 1029-1048.

Milliman, J.D., Jiezao, Z., Anchun, L., Ewing, J., 1990. Late Quaternary sedimentation on the outer andmiddle New Jersey continental shelf: result of two local deglaciations? Journal of Geology 98, 966-976.

Mitchum, R.M. Jr., Vail, P.R., Sangree, J.B., 1977a. Seismic stratigraphy and global changes of sea level; Part 6, Stratigraphic interpretation of seismic reflection patterns in depositional sequences. In: Seismic Stratigraphy: Application to Hydrocarbon Exploration. American Association of Petroleum Geologists Memoir 26, 117-133.

Mitchum, R.M., Vail, P.R., Sangree, J.B., 1977b. Seismic stratigraphy and global changes of sea level, part 7: Seismic stratigraphy interpretation procedures. In: Payton, C.E. (Ed.), Seismic Stratigraphy: Application to Hydrocarbon Exploration. American Association of Petroleum Geologists Memoir 26, 135-143.

Modica, C.J.; Brush, E.R., 2004. Postrift sequence stratigraphy, paleogeography, and fill history of the deep-water Santos Basin, offshore southeast Brazil. Bulletin of the American Association of Petroleum Geologists 88, 923-945.

Nagai, R.H., Mello e Sousa, S.H., Lourenço, R.A., Bícego, M.C., Mahiques, M.M., 2010. Paleoproductivity changes during the late Quaternary in the southeastern Brazilian upper continental margin of the southwestern Atlantic. Brazilian Journal of Oceanography 58 (no.spe2), 31-41.

Plint, A.G., Nummedal, D., 2000. The falling stage systems tract: recognition and importance in sequence stratigraphy. In: Hunt, D., Gawthorpe, R.L. (Eds.), Sedimentary responses to forced regressions. Geological Society of London, pp. 1-17.

Rabineau, M., Berné, S., Aslanian, D., Olivet, J.L., Joseph, P., Guillocheau, F., Bourillet, J.F., Ledrezen, E., Granjeon, D., 2006. Paleo sea levels 
reconsidered from direct observation of paleoshoreline position during Glacial Maxima (for the last 500,000 yr). Earth and Planetary Science Letters 252, 119-137.

Rocha, J., Milliman, J.D., Santana, C.I., Vicalvi, M.A., 1975. Continental margin sedimentation off Brazil Part 5: Southern Brazil. Contributions to Sedimentology 4, 117-150.

Rodrigues, R.R., Lorenzzetti, J.A., 2001. A numerical study of the effects of bottom topography and coastline geometry on the Southeast Brazilian coastal upwelling. Continental Shelf Research 21, 371-394.

Rohling, E.J., Fenton, M., Jorissen, F.J., Bertrand, P., Ganssen, G., Caulet, J.P., 1998. Magnitudes of sea level lowstands of past 500,000 years. Nature 394, 162-165.

Schattner, U., Lazar, M., Tibor, G., Ben-Avraham, Z., Makovsky, Y., 2010. Filling up the shelf - A sedimentary response to the last post-glacial sea rise. Marine Geology 278, 165-176

Shackleton, N.J., 2000. The 100,000-year Ice-Age cycle identified and found to lag temperature, carbon dioxide, and orbital eccentricity. Science 289, 1897-1902.

Siddall, M., Almogi-Labin, R.E. J. A., Hemleben, C., Meischner, D., Schmelzer, I., Smeed, D.A., 2003. Sea-level fluctuations during the last glacial cycle. Nature 423, 853-858.

Signorini, S.R., 1978. On the circulation and the volume transport of the Brazil Current between the Cape of São Tomé and Guanabara Bay. Deep-Sea Research 25, 481-490.

Silveira, I.C, Schmidt, A., Campos, E., Godoi, S., Ikeda, Y., 2000. A corrente do Brasil ao largo da costa leste brasileira. Revista Brasileira de Oceanografia. 48, 171-183 (in Portuguese).

Skene, K.I., Piper, D.J.W., Aksu, A.E., Syvitski, J.P.M., 1998. Evaluation of the global oxygen isotope curve as a proxy for Quaternary sea level by modeling of delta progradation. Journal of Sedimentary Research 68, 6, 1077-1092.

Smith, W.H.F, Sandwell, D.T., 1997. Global Seafloor topography from satellite altimetry and ship depth soundings. Science 227, 1956-1962.

Soutelino, R.G., 2008. A origem da corrente da Brasil. 2008. Master dissertation, Instituto Oceanográfico. Universidade of São Paulo (USP), São Paulo, Brazil (in Portuguese). 
Stanley, D.J., Moore, G.T., 1983. The shelfbreak: critical interface on continental margins. Society of Economic Paleontologist and Mineralogist Special Publication 33, 467 pp.

Stramma, L., England, M., 1999. On the water masses and mean circulation of the South Atlantic Ocean. Journal of Geophysical Research 104 (C9), 20863-20883.

Szabo, B.J., Ludwig, K.R., Muhs, D.R., Simmons, K.R., 1994. Thorium- 230 ages of corals and duration of the last interglacial sea-level high stand on Oahu, Hawaii. Science 266, 93-96.

Toscano, M.A., Lundberg, J., 1999. Submerged Late Pleistocene reefs on the tectonically-stable SE Florida margin: high precision geochronology, stratigraphy, resolution of Substage 5a sea-level elevation, and orbital forcing. Quaternary Science Reviews 18, 753-767.

Waelbroeck C., Labeyrie L.D., Michel E., Duplessy J.-C., McManus, J. Lambeck K., Balbon E., Labracherie M., 2002. Sea level and deep water changes derived from benthic Foraminifera isotopic record, Quaternary Science Reviews 21, 295-305.

Zalán P.V., Oliveira J.A.B., 2005. Origem e evolução estrutural do Sistema de Riftes Cenozóicos do Sudeste do Brasil. Boletim de Geociências da Petrobras 13, 269-300 (in Portuguese).

Zembruscki, S.G., 1979. Geomorfologia da margem continental sul-brasileira e das bacias oceânicas adjacentes. In: Chaves, H.A.F. (Ed.). Geomorfologia da margem continental brasileira e das bacias oceânicas adjacentes. Projeto REMAC 7. Petrobrás, Rio de Janeiro, pp 129-177 (in Portuguese).

\section{FIGURE CAPTION}

Figure 1: Regional bathymetry of the continental shelf off Rio de Janeiro State, northern Santos basin, with location of the study area, tracklines of singlechannel seismic data and exploratory wells. Regional bathymetry from ETOPO2 (Smith and Sandwell, 1997). 
972 Figure 2: Distribution of surface sediments in the study area. Redrawn from 973 Figueiredo and Tessler (2004) over ETOPO2 regional bathymetry (Smith and 974 Sandwell, 1997).

976 Figure 3: (A) Interpreted dip single-channel seismic line (sparker $1000 \mathrm{~J}$ ) across 977 the eastern shelf sector off Rio de Janeiro State, illustrating a lower 978 aggradational-progradational stratigraphic Set I and Set II (modified from Maia 979 et al., 2010; Set II encompasses Middle-Upper Pleistocene deposition: last 440$980500 \mathrm{Kyr}$ ). (B) Sequence boundaries S1 to S5, topping successive 4th order 981 sequences Sq1 to Sq4. Sq5 corresponds to Holocene transgressive and highstand 982 deposition from the current half-cycle (post-LGM). Note offlapping distal oblique clinoforms within Sq2 to Sq4, showing significant stepped morphology, imprinted on respective palaeo-sea-floors and the present shelf sea floor. (C) Proposed depositional cyclicity based on correlation with $\delta^{18} \mathrm{O}$-derived global sea level variations compiled by Rabineau et al. (2006).

987

Figure 4: Serial bathymetric cross-sections aligned roughly $\mathrm{N}-\mathrm{S}$, showing 989 progressive east-west changes in morphology and width of the continental shelf off southern Rio de Janeiro State. Bathymetric data are a compilation of over 50 years of bathymetric sounding charts acquired by the Brazilian Navy.

Figure 5: Shelf morphological map off southern Rio de Janeiro State, highlighting shelf-scale contour-parallel sea-floor features, mapped with the aid of high-resolution seismic analysis and bathymetric data. Dotted thick lines represent buried escarpments. Features 1 to 9 are discussed in the text.

Figure 6: Conjugated bathymetric and seafloor gradient map off southern Rio de Janeiro State. Bathymetric data are a compilation of over 50 years of bathymetric sounding charts acquired by the Brazilian Navy, made available by CHM-Centro Hidrográfico da Marinha do Brasil.

Figure 7: Sub-bottom dip profile (frequency chirp $\sim 0,5-5,5 \mathrm{kHz}$, top) and interpreted line drawing (bottom) across the central shelf sector off Rio de Janeiro State. Chirp profiles revealed further architectural detail in the upper sequences ( $\mathrm{Sq} 3$ to $\mathrm{Sq} 5$ ), originating from alternating marine deposition and subaerial erosion encompassing the last few Quaternary climate cycles 
(presumably the youngest $230-250 \mathrm{kyr}$ ). (T-R) Composite transgressiveregressive wedge, (Tr) Transgressive units, (Hs) Highstand units, (FSST) Fallingstage Systems Tract, (HST) Highstand Systems Tract, (S3-S5) Unconformities, (E) Sea-floor escarpments.

Figure 8: Extracts of sub-bottom cross-section profiles (frequency chirp $\sim 0,5$ $5,5 \mathrm{kHz}$ ) extending over the mid-outer shelf seaward from the $\sim 100-\mathrm{m}$ isobath. The $-110 \mathrm{~m}$ and $-130 \mathrm{~m}$ laterally-continuous sea-floor escarpments are erosive imprints of S5 lowstand exposure surface. The distal escarpment at - $150 \mathrm{~m}$ water depth, and associated seaward-inclined basal terrace, shows evidence of accentuated erosion, probably in response to contour currents. (E) Sea-floor escarpments, (Tr) Transgressive units, (FRw) Forced-regressive wedges, (S1-S5) Unconformities.

Figure 9: Extracts of sub-bottom cross-sections ( $\mathrm{A}$ and $\mathrm{B}$ ) and sparker seismic lines, located at the shelfbreak along the western shelf-edge embayment, showing the lateral variability of the $-150 \mathrm{~m}$ escarpment (E) and basal seawardinclined terrace. $(\mathrm{Cr})$ Carbonate bioconstructions.

Figure 10: Envelope of sea-level curves based on $\delta^{18} \mathrm{O}$ isotopic ratio's and calibrated by the dating of geological evidence globally (see text and references), and correlation of the S4 and S5 unconformities in the study area to it.

Figure 11: Sub-bottom strike profile (frequency chirp $\sim 0,5-5,5 \mathrm{kHz}$; top) and interpreted line drawing (bottom) across the outer shelf off southern Rio de Janeiro State. Overall thickness reduction of sequences Sq3 and Sq4 within the shelf corridors evidence the significant erosion forming these elongated depressions across the mid-outer shelf (see Figs. 5 and 15 for plan views). (Tr) Transgressive units, (FSST) Falling-Stage Systems Tract, (S3-S5) named unconformities.

Figure 12: Sub-bottom dip profile (frequency chirp $\sim 0,5-5,5 \mathrm{kHz}$; top) and interpreted line drawing (bottom) crossing the Western Shelf Corridor. This particular section shows sequence Sq4 to be deeply eroded so that erosional surfaces S5 and S4 have merged over most of the mid-outer shelf, leaving a a composite and smooth-topped erosional surface that apparently obliterated the 
morphological relief of the $-110 \mathrm{~m}$ and $-130 \mathrm{~m}$ escarpments. (Tr) Transgressive units, (FSST) Falling-stage Systems Tract, (S3-S5) Unconformities, (E) Sea-floor escarpments.

Figure 13: Extracts of sub-bottom cross-section profiles (frequency chirp $\sim 0,5$ $5,5 \mathrm{kHz}$ ) located landward from the 100-m isobath, showing east-west differences in inner-mid shelf morphology and architecture, with westward higher preservation of young composite transgressive and highstand features (Sq5), in relation to such feature preservation for next-older sequence (Sq4) and bounding erosion surfaces (S4, S5).

Figure 14: Extracts of sub-bottom profiles (frequency chirp $\sim 0,5-5,5 \mathrm{kHz}$ ) showing carbonate bioconstructions, locally as thick as $10 \mathrm{~m}$, to be widespread across areas of the mid-outer shelf seaward from the 100-m isobath.

Figure 15: Simplified geomorphological map of the continental shelf off southern Rio de Janeiro State linking high-resolution seismic analysis with the occurrence of laterally-continuous drowned sea-floor features resulting from Late Pleistocene sea level oscillations (i.e. in the last $\sim 120 \mathrm{kyr}$ ). Dotted thick lines represent buried escarpments.

Figure 16: Simple conceptual stratigraphic model relating the origin of linear, stepped sea-floor features along the continental shelf off Rio de Janeiro State to the eustatic sea-level (SL) regressive scenario between MIS5e and MIS2 (Late Pleistocene). The inset curve is derived from Labeyrie et al. (1987), with T-R = Composite transgressive-regressive wedge and FSST = Falling-stage Systems Tract: (A-D) sediments related to the older part of the cycle, when sea-level was still relatively high are deposited on the inner shelf, with several subunits that may be related to higher frequency sea-level oscillations (MIS 5e-5a and MIS 4); (E-F) sediments related to the younger part of the regressive cycle (MIS 3 to MIS 2) are deposited as forced regressive sequences on the outer shelf. The $-110 \mathrm{~m}$ escarpment is sculpted between MIS 3 and MIS 2 (between $t 4$ and t6). The -130 $\mathrm{m}$ escarpment relates to the LGM shoreline (at $t 6$ ); (G) The $-150 \mathrm{~m}$ scarp marks enhanced erosion due to shelfward migration of the Brazil Current during the post-LGM transgression (between $t 6$ and $t 7$ ). 


\section{Figure}

Click here to download high resolution image

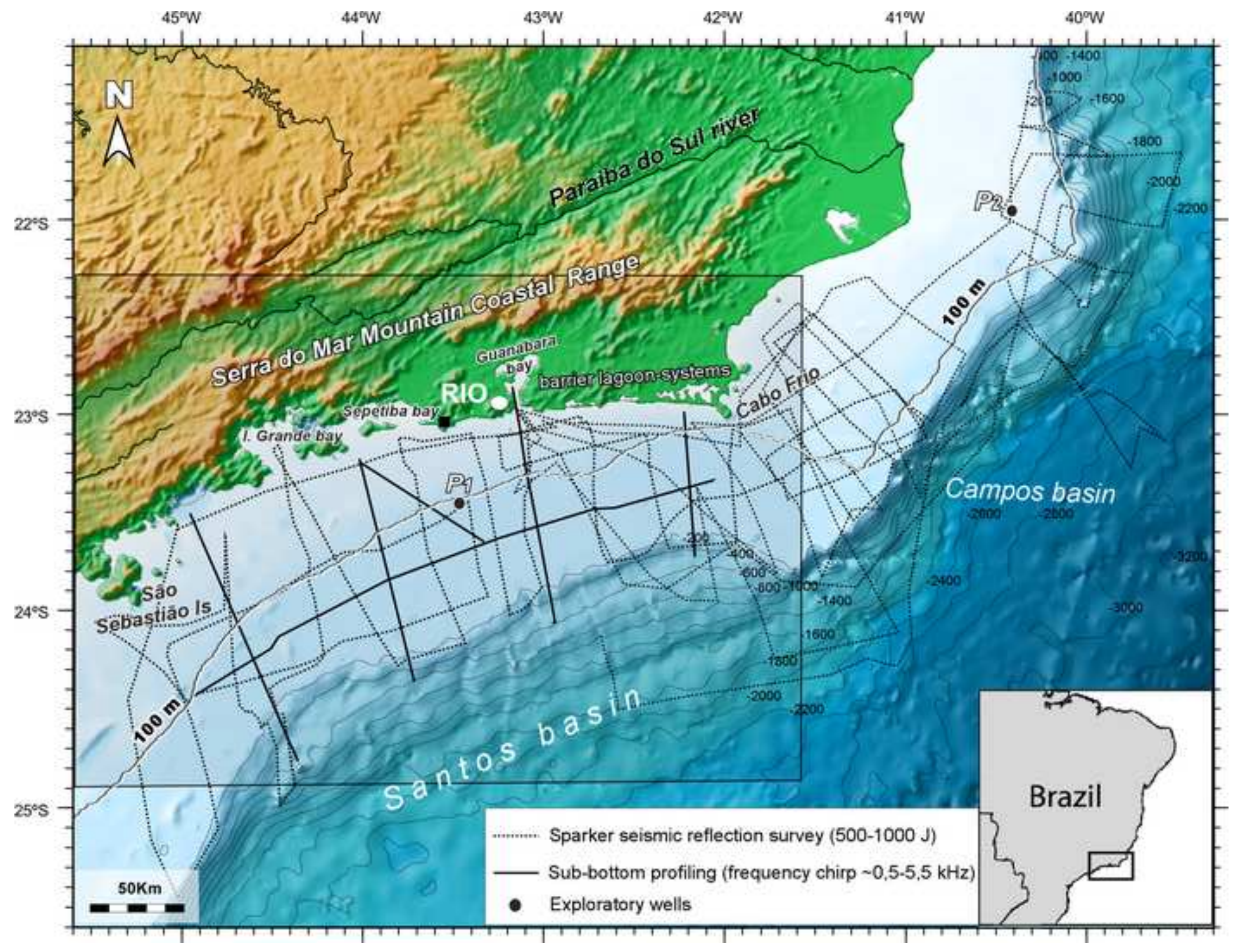


Click here to download high resolution image

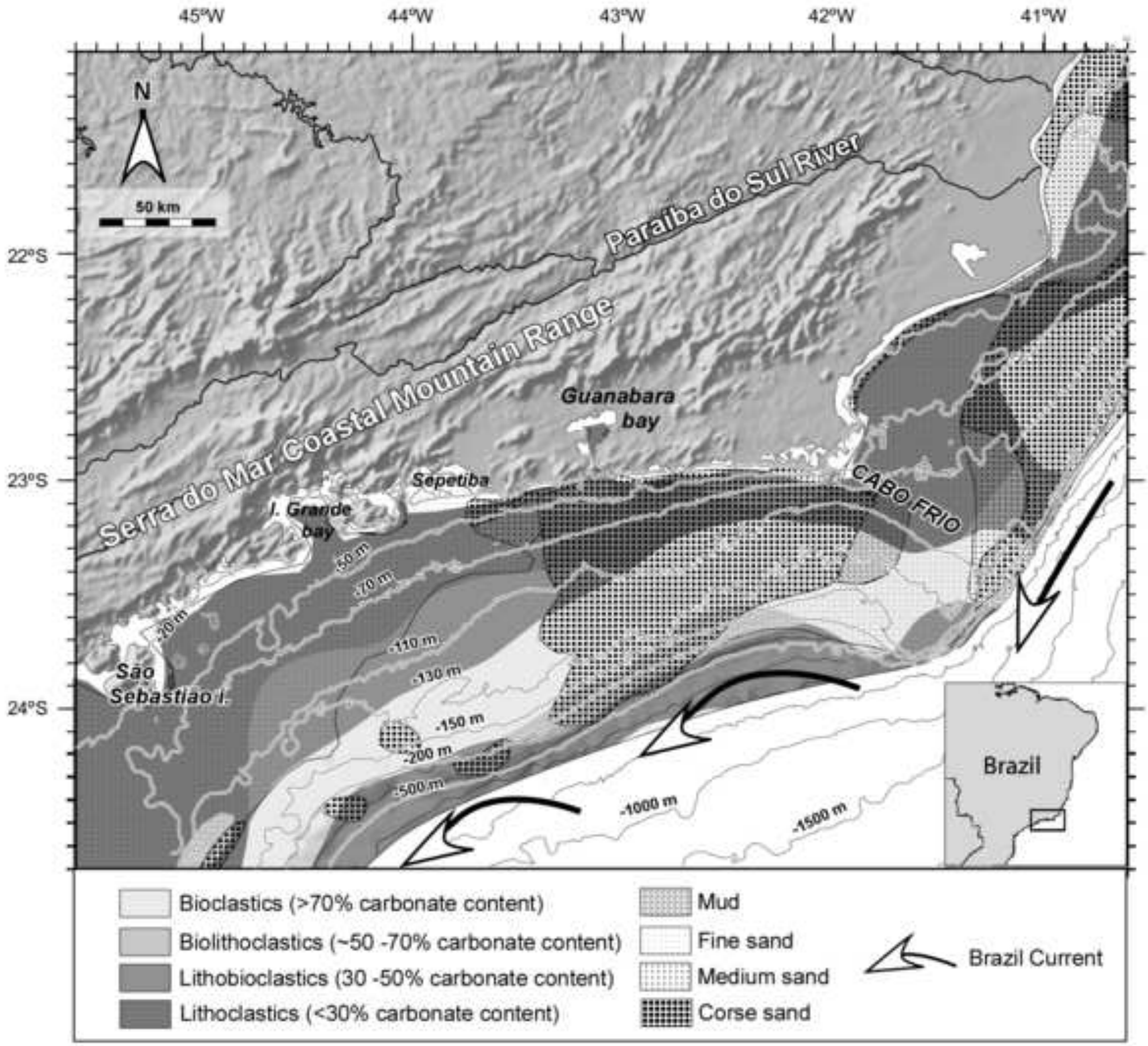


B A

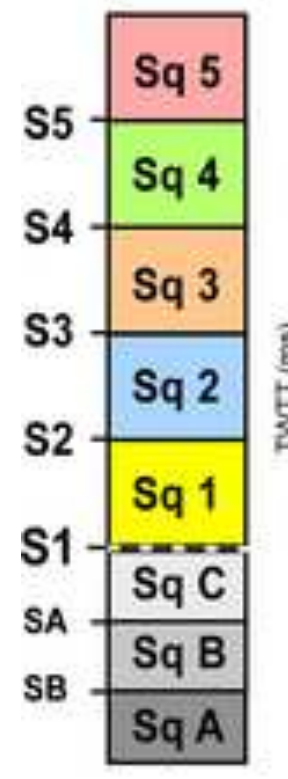

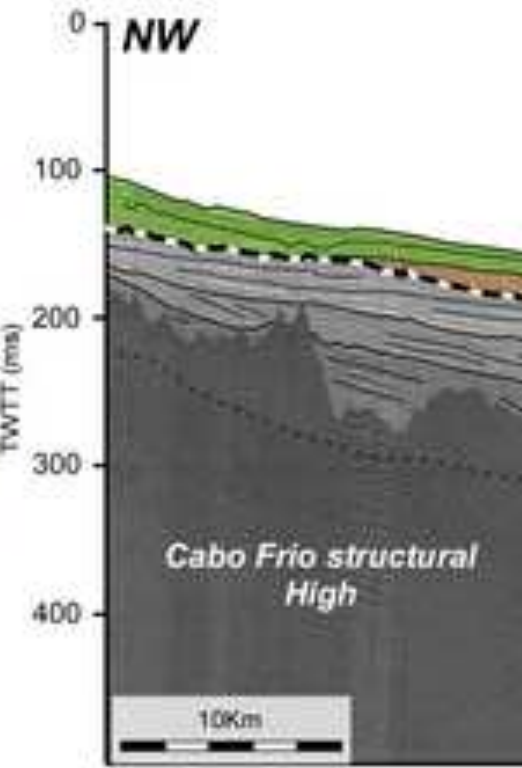

\begin{tabular}{|l|l|l|l|l|l|l|l|l|l|l|} 
MIS & 24 & 5 & 0 & 7 & 8 & 9 & 10 & 11 & 12 & 13 \\
\hline
\end{tabular}

C

$\underline{E}_{20} \stackrel{0}{*} \quad 100 \quad 200 \quad 300 \quad 400 \quad 500$ (kyr)

ए 0 ฮ 0 \$. 20 范 -40 造 -60 a. -60 $\frac{8}{9}-80$ $\sum^{-80}$ 量- 100 空-120 要 120 I $-140 \cdot$ (S5) $1-$

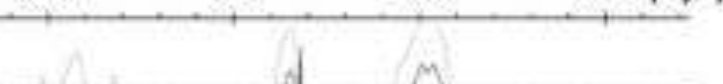

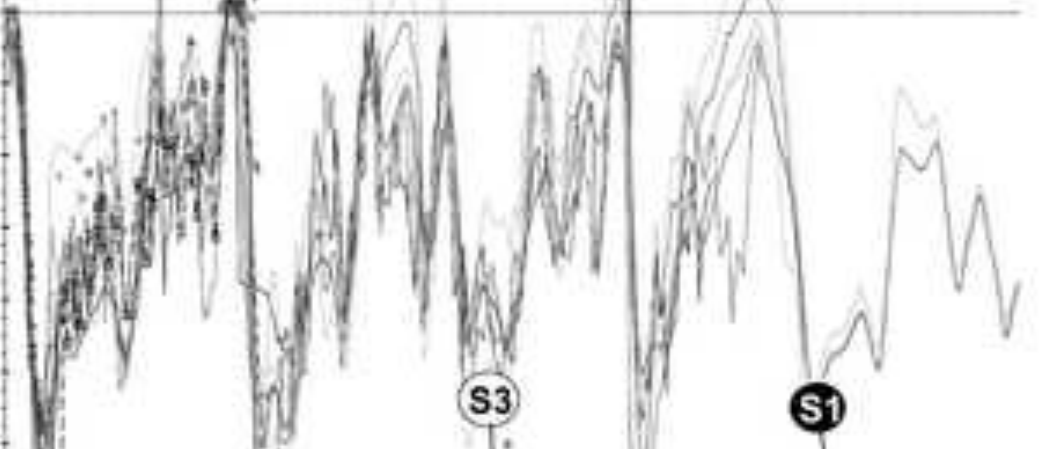

(33)

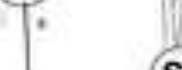

(5)

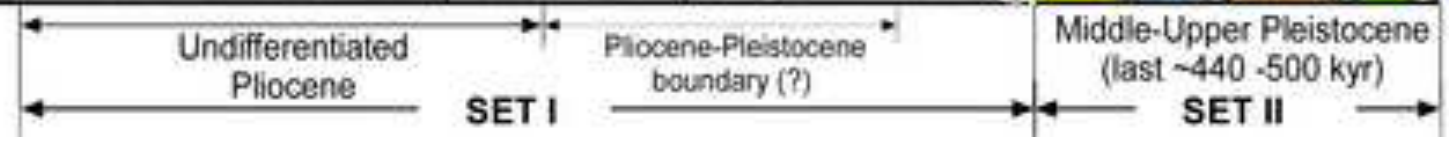


Click here to download high resolution image

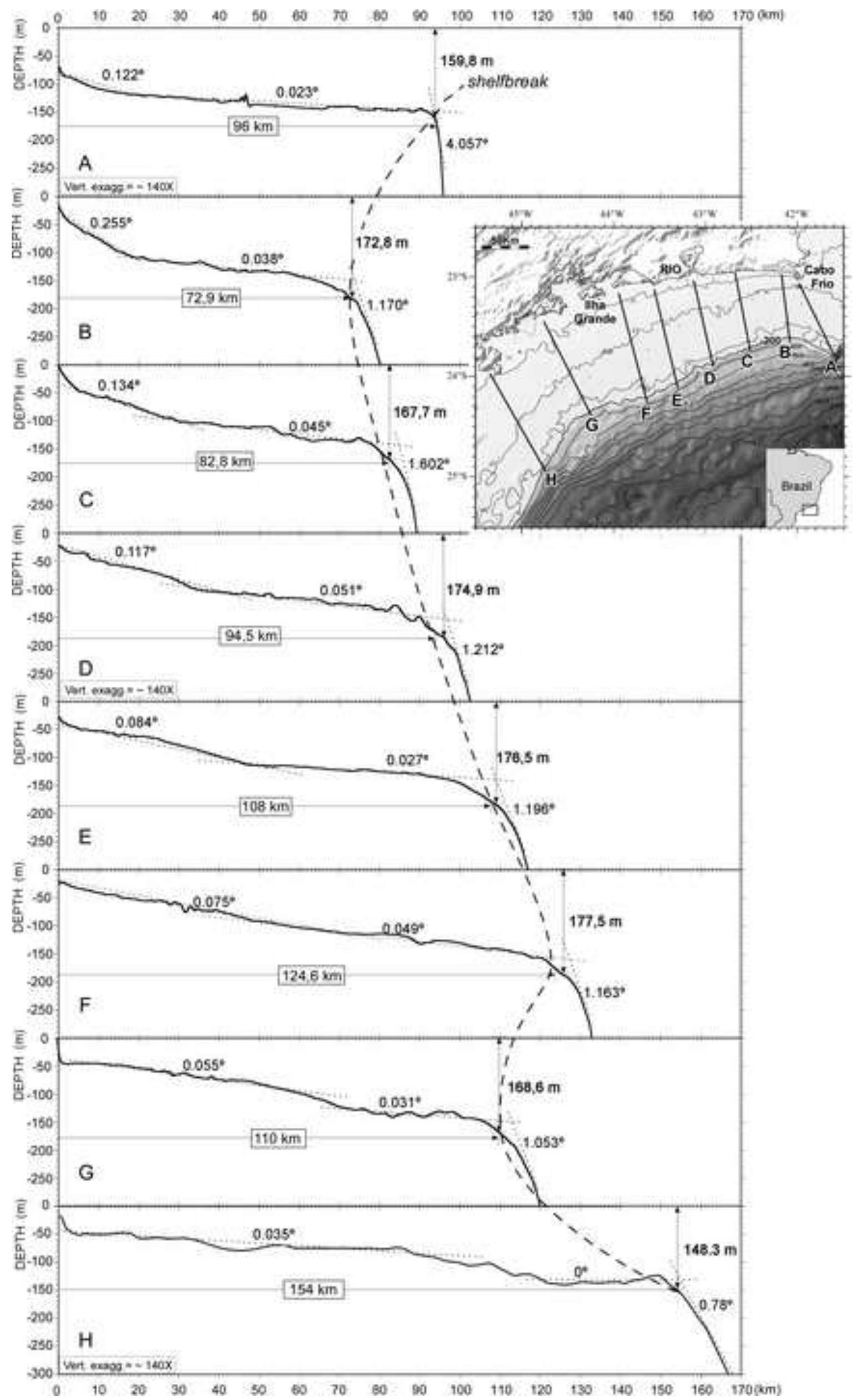




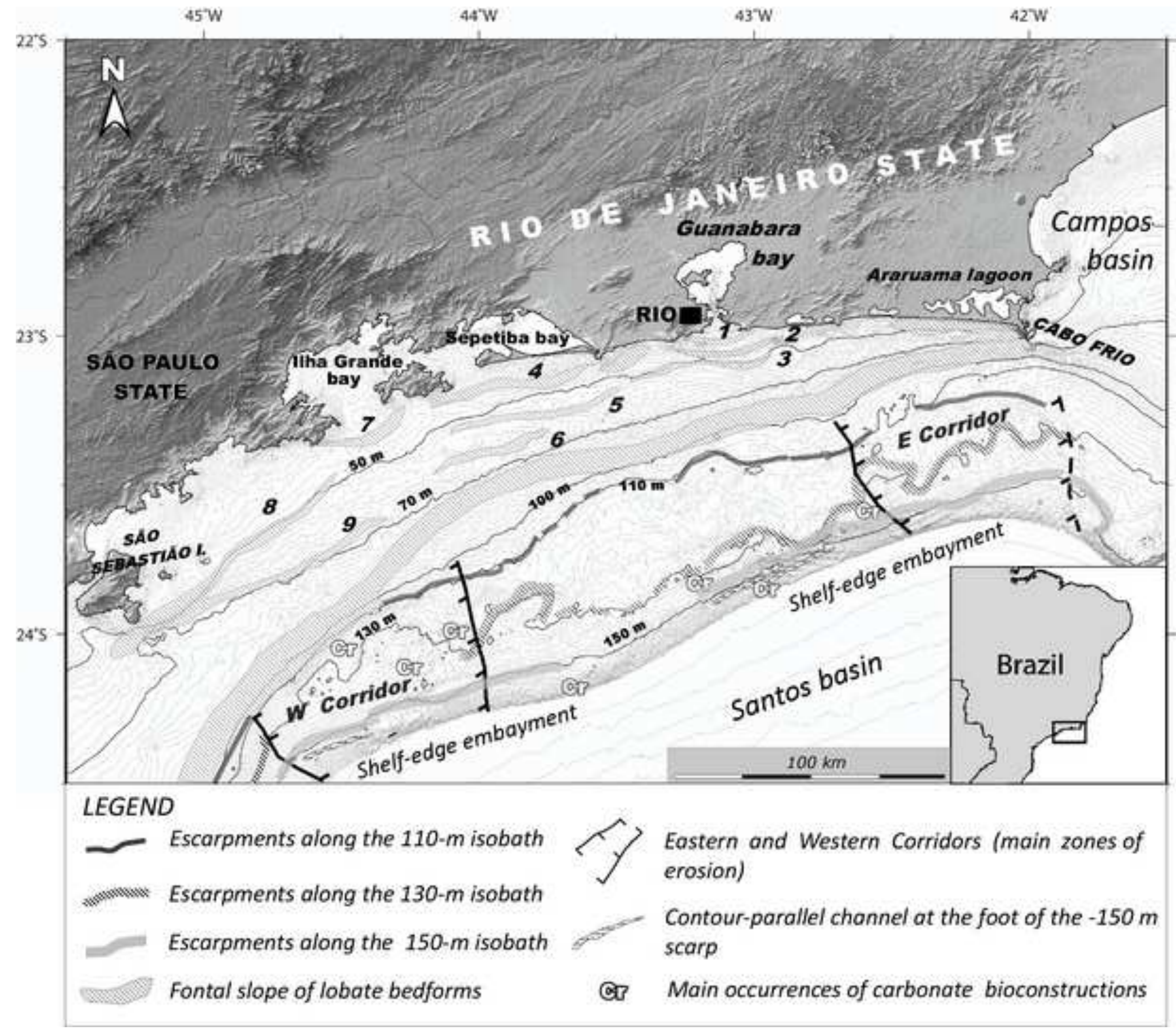


Click here to download high resolution image

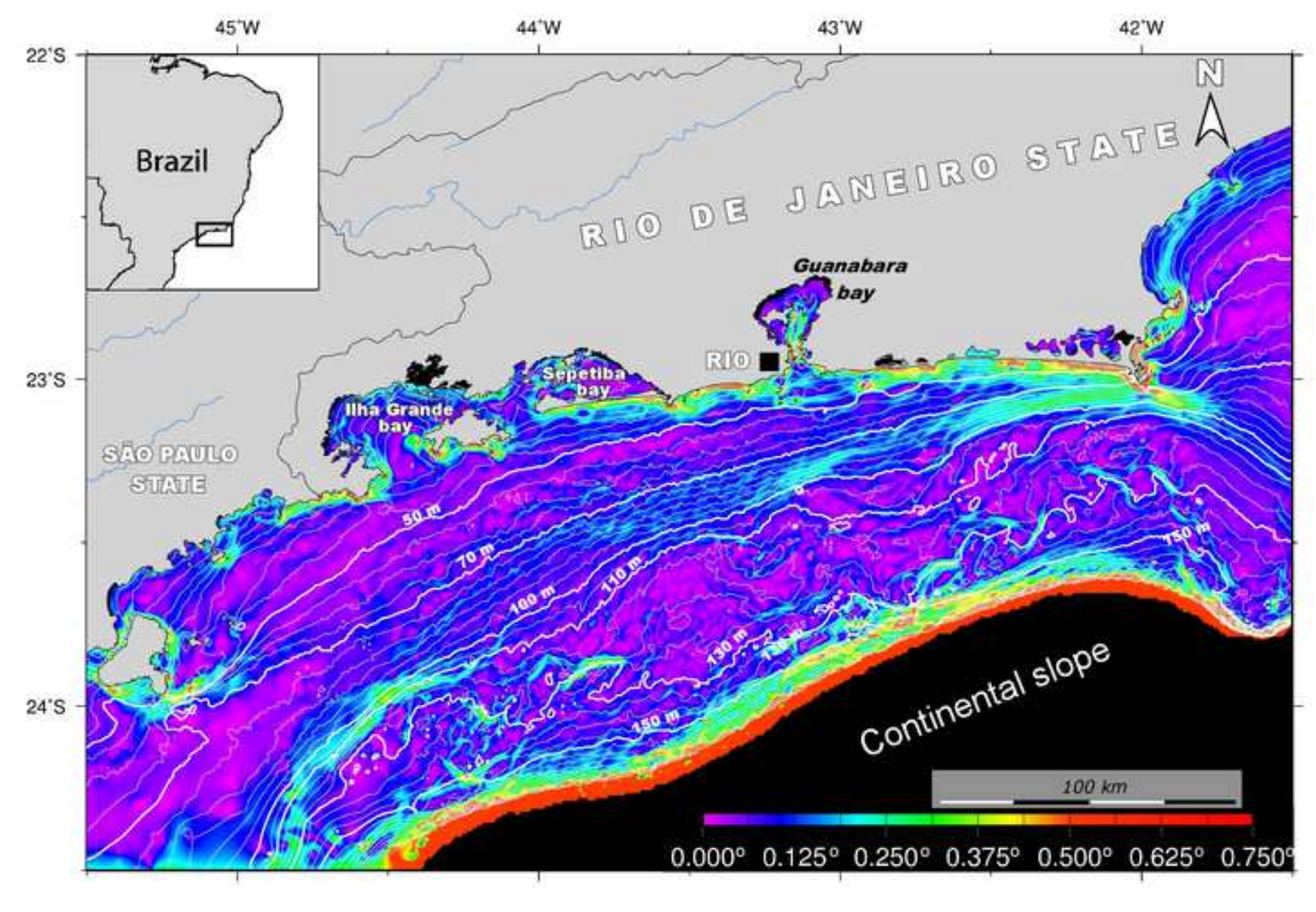


Click here to download high resolution image
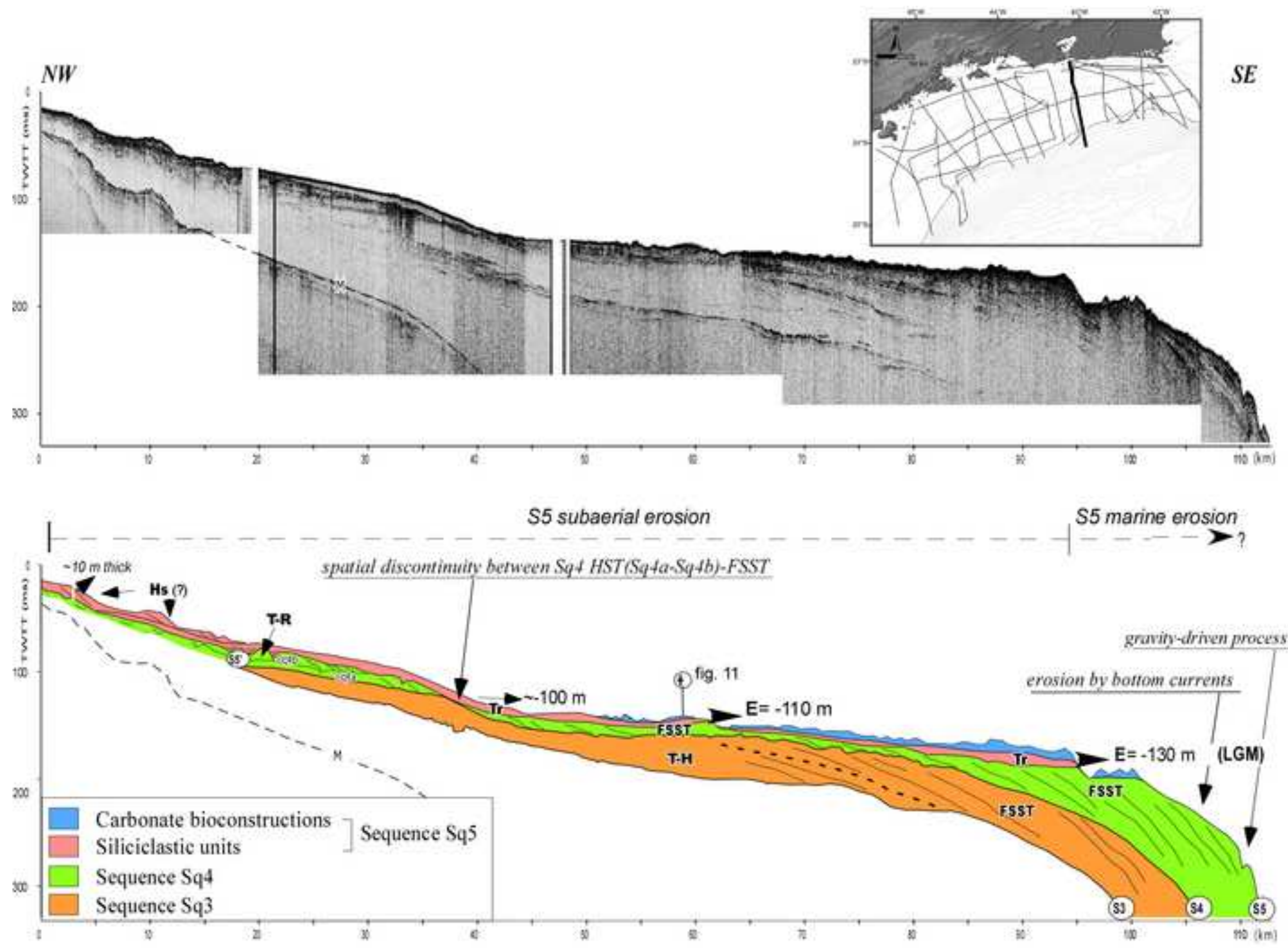
Click here to download high resolution image
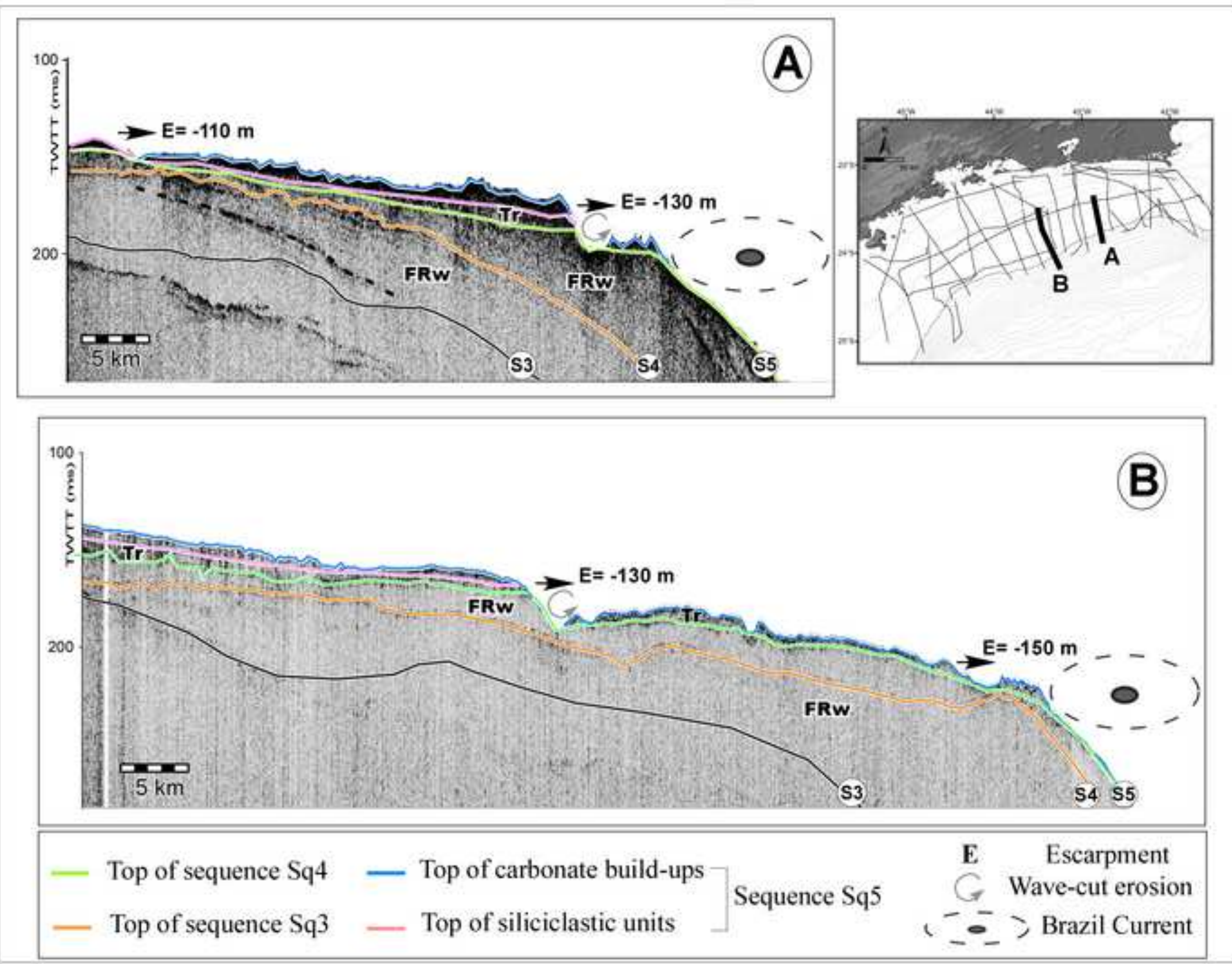

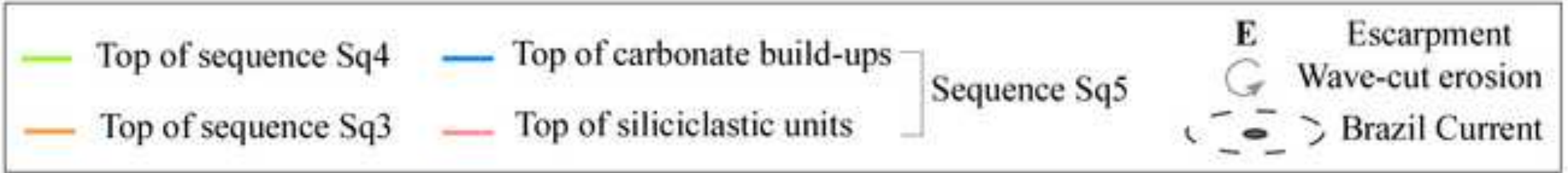




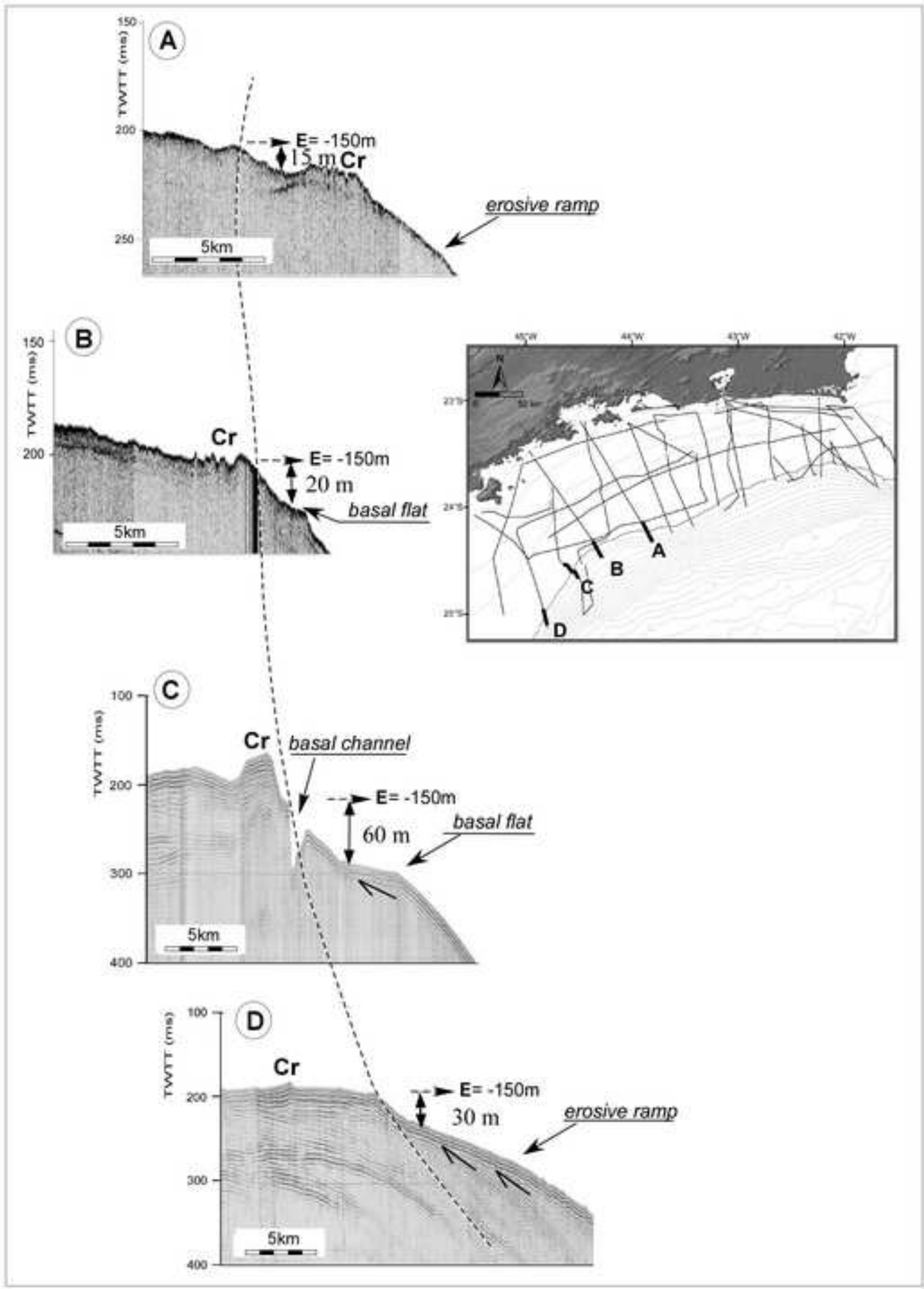


Click here to download high resolution image

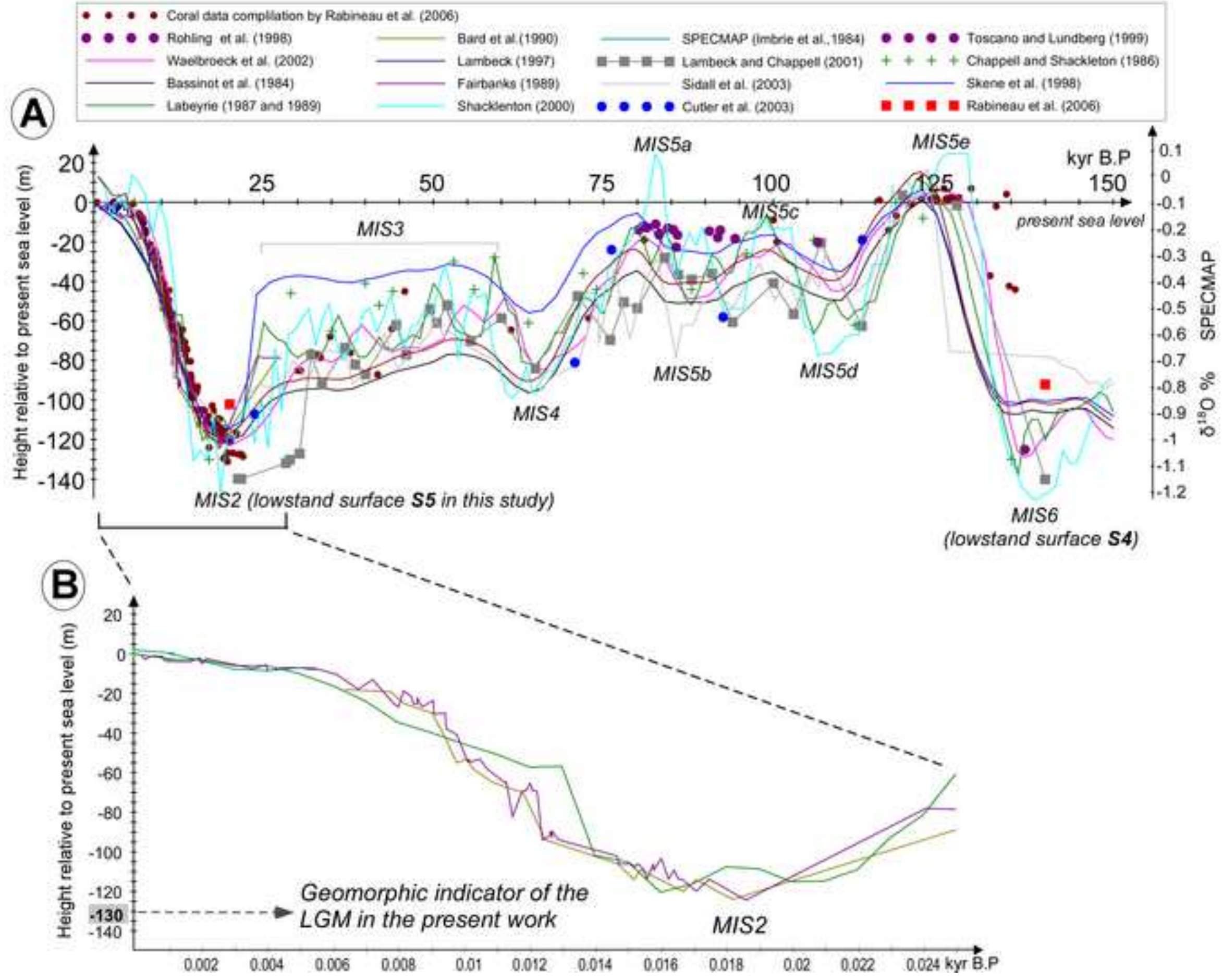


Click here to download high resolution image

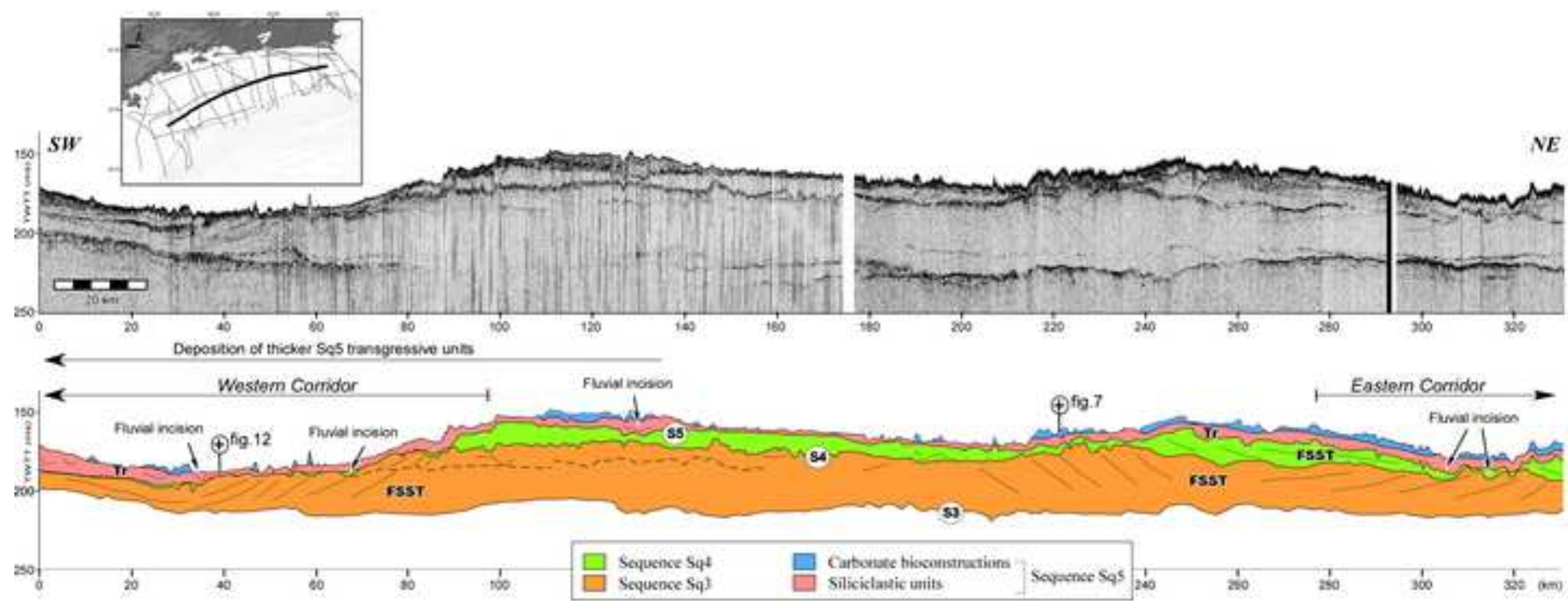


Click here to download high resolution image

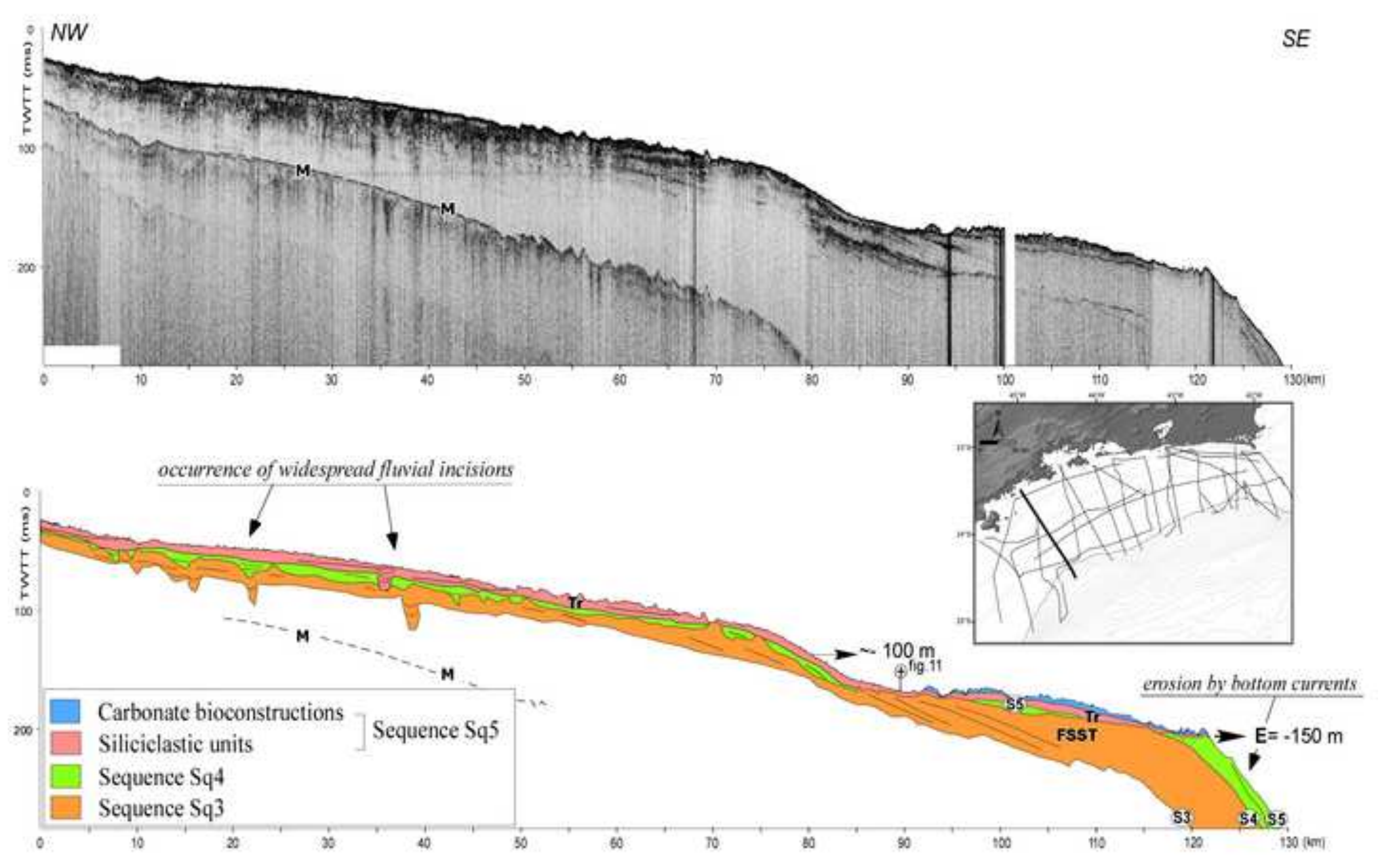

Click here to download high resolution image

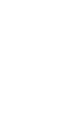

(1)

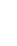

,

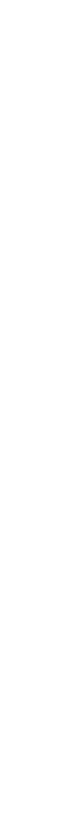



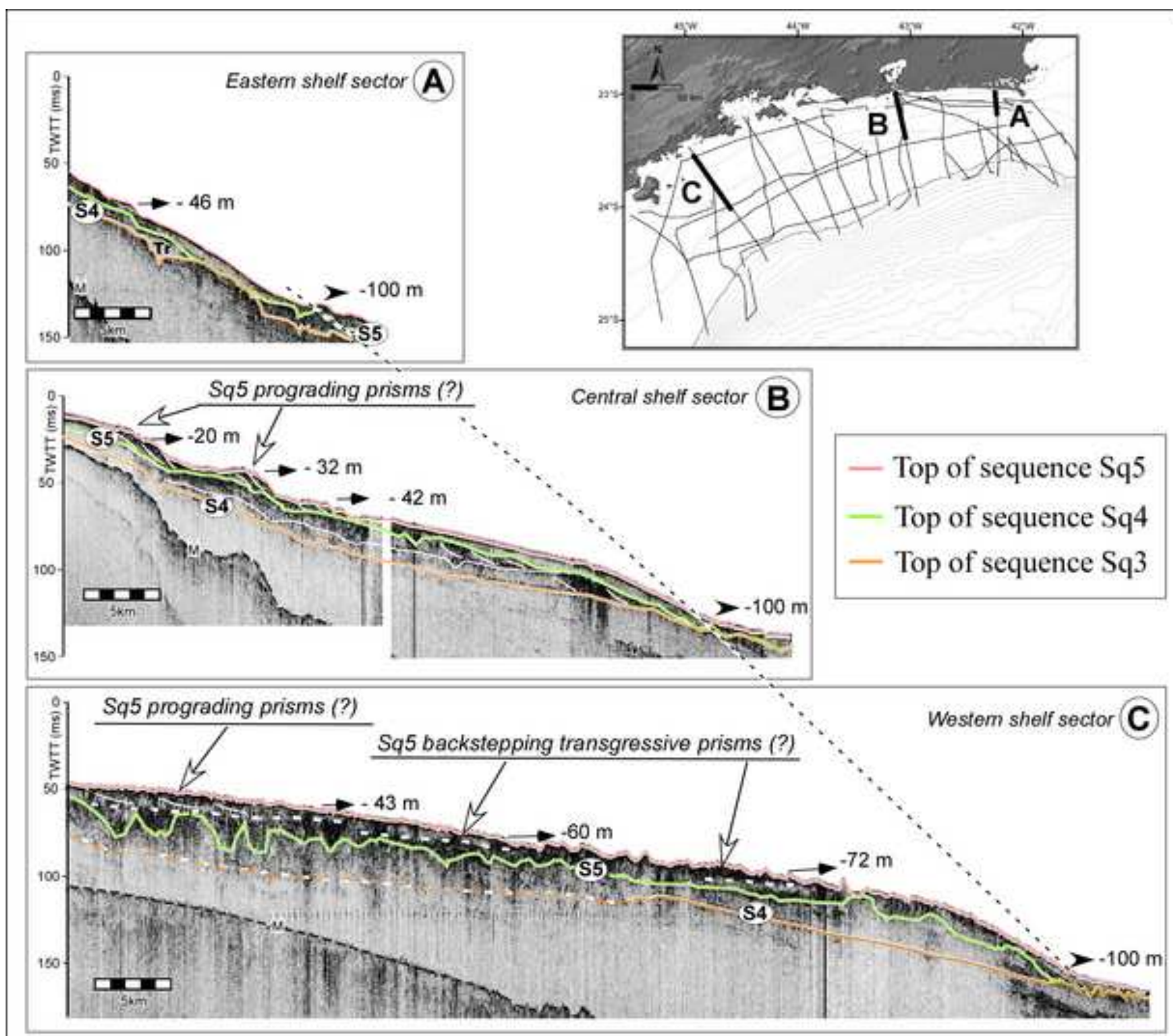
Click here to download high resolution image

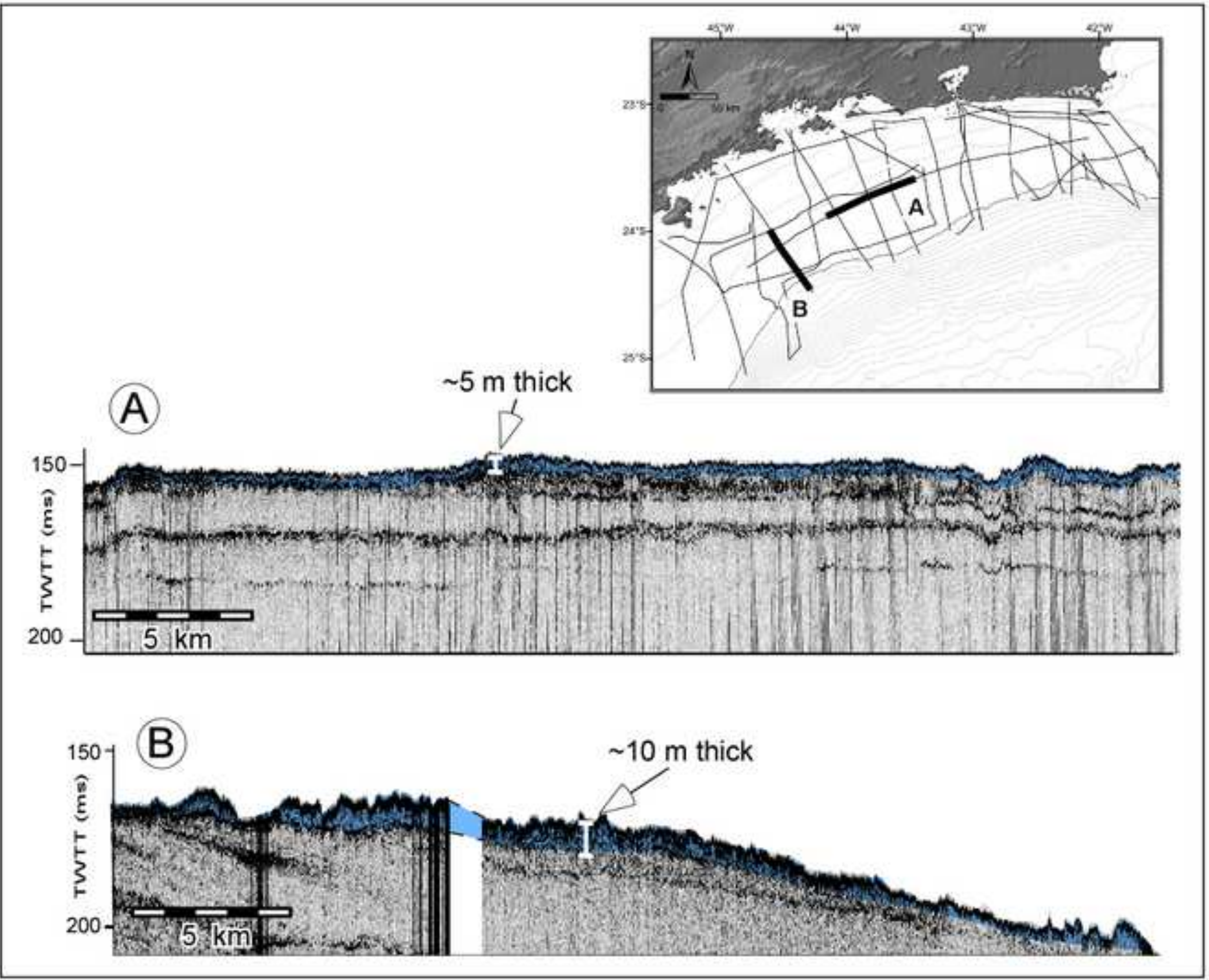




\section{Click here to download high resolution image}

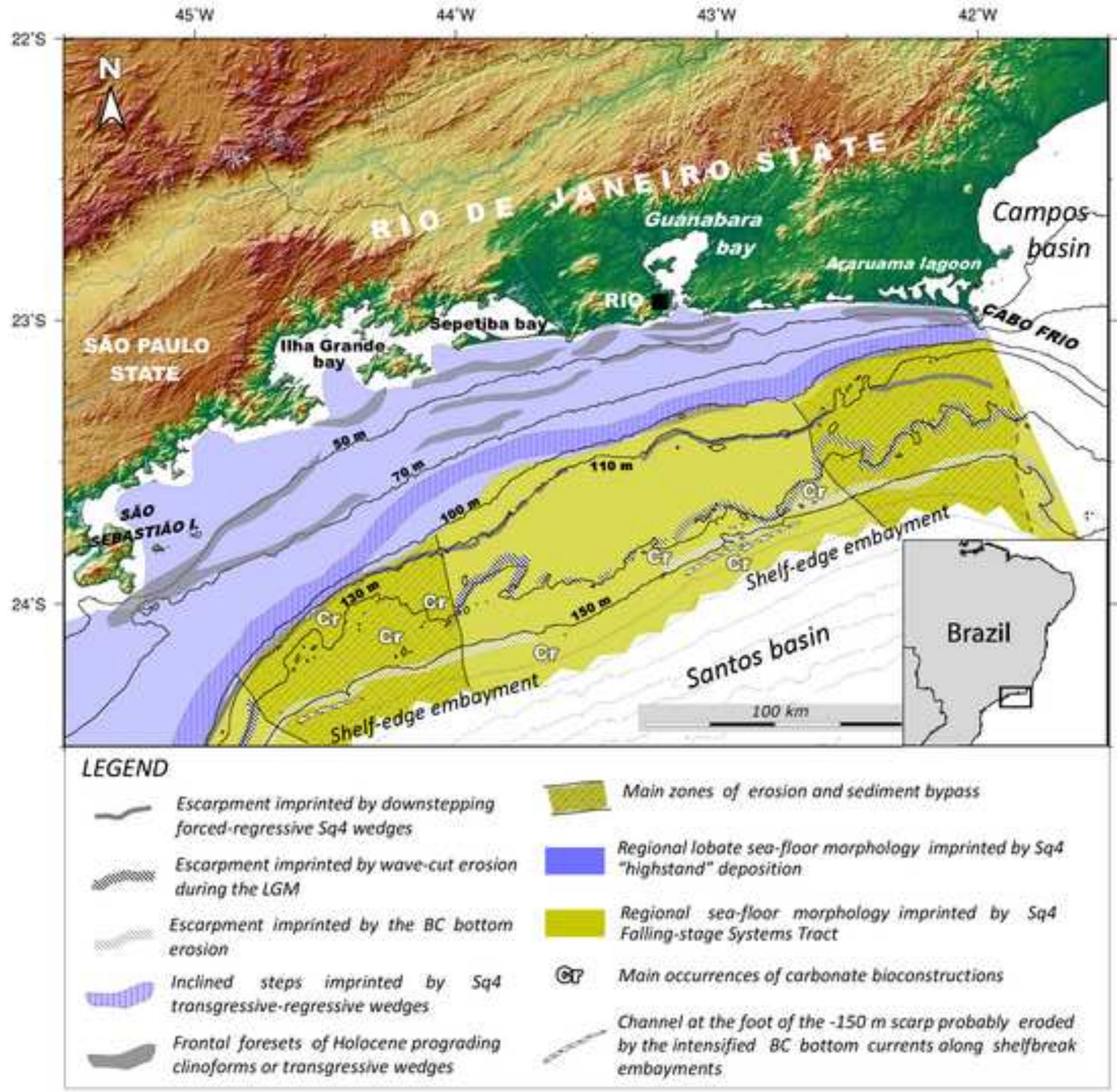




\section{Figure16}

Click here to download high resolution image

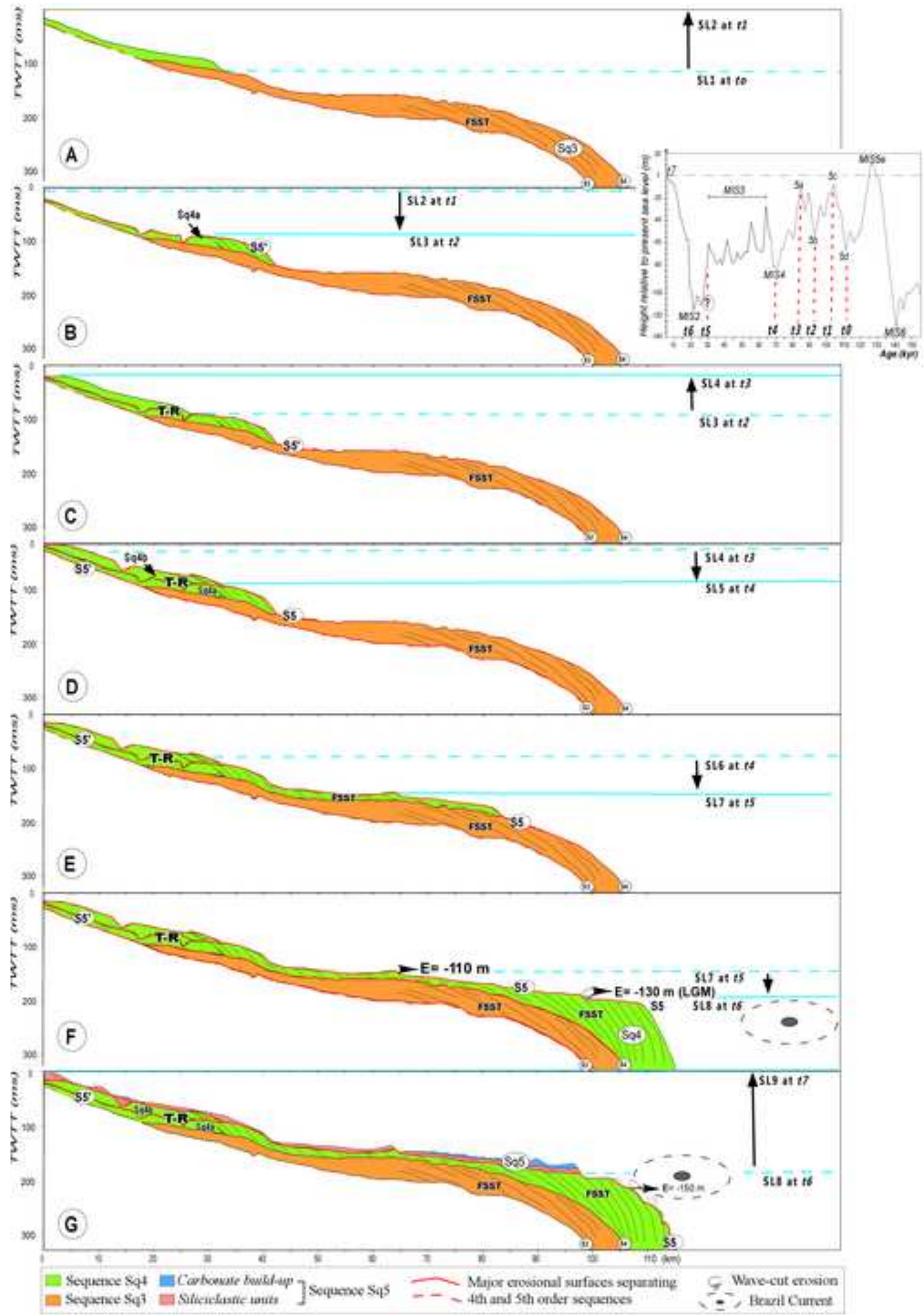

